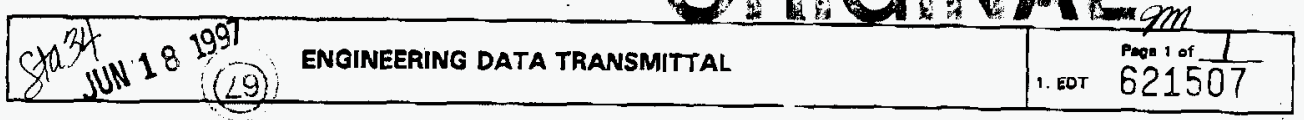

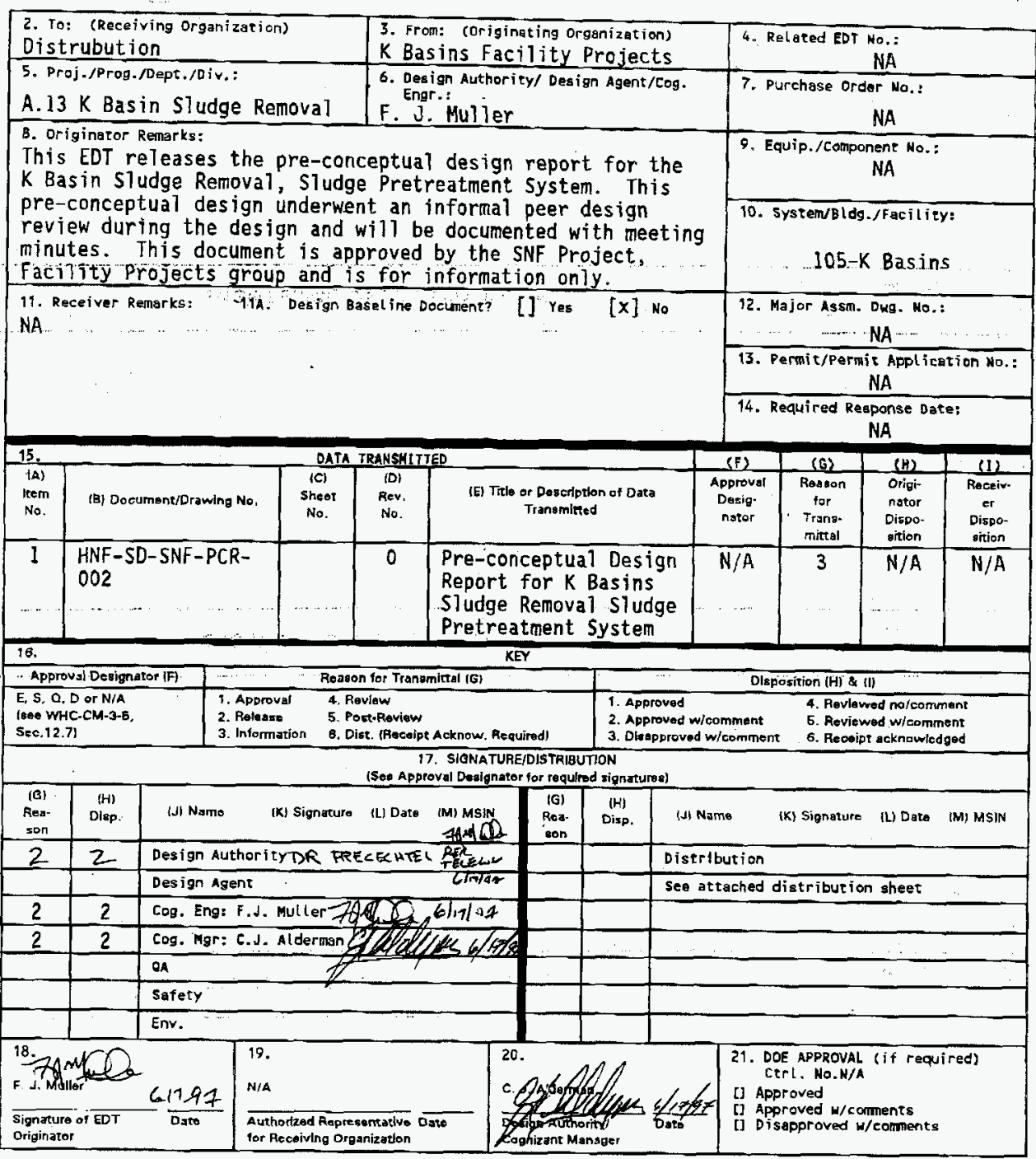

BD-7400- $172-2(05 / 96)$ GEFO97 


\title{
K Basin Sludge Removal Sludge Pretreatment System
}

\author{
H. L. Chang \\ Fluor Daniel Northwest, Richland, WA 99352 \\ U.S. Department of Energy Contract DE-AC06-96RL13200
}

EDT/ECN: 621507

Org Code: 04E00/454

UC: 603

Charge Code: E33937

B\&R Code: EW7050000 Total Pages: 65

Key Words: K Basin, Sludge, Pretreatment

Abstract: After the fuel is removed from $K$ Basins, the remaining sludge at the bottom of the basins must be extracted and processed to be made acceptable for TWRS disposal. This preconceptual design report expands the modular subsystem alternative recommended in Engineering Study HNF-SD-SNF-ES-024. The concept is to provide tightly sealed safety class containment structures of the Conex container type that will accommodate the sludge processing including dewatering, washing, dissolution $\left(\mathrm{HNO}_{3}\right)$, precipitation $(\mathrm{NaOH})$, offgas treatment, $\mathrm{pH}$ adjustment, re-constitution and loadout. The process location is at $\mathrm{K}$ Basins in the 100 Area.

TRADEMARK DISCLAIMER. Reference herein to any specific commercial product, process, or service by trade name, trademark, manufacturer, or otherwise, does not necessarily constitute or imply its endorsement, recommendation, or favoring by the United States Government or any agency thereof or its contractors or subcontractors.

Printed in the United States of America. To obtain copies of this document, contact: Document Control Services, P.O. Box 950, Mailstop H6-08, Richland WA 99352, Phone (509) 372-2420; Fax (509) 376-4989.
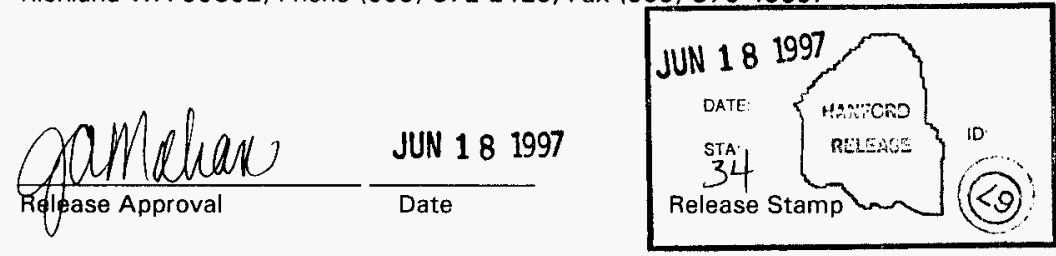

Approved for Public Release

A-6400-073 (10/95) GEF321 


\section{Preconceptual Design Report}

\section{K Basins Sludge Removal Sludge Pretreatment System}

Work Order E33937

Prepared for the U.S. Department of Energy

Assistant Secretary for Environmental Management

Project Hanford Management Contractor for the

U.S. Department of Energy under Contract DE-AC06-96RL13200

Approved for public release; distribution is unlimited 
PRECONCEPTUAL DESIGN REPORT

\section{K BASINS SLUDGE REMOVAL SLUDGE PRETREATMENT SYSTEM \\ WORK ORDER E33937}

Prepared for

DE\&S Hanford, Inc.

June 1997

Prepared by

Fluor Daniel Northwest

Richland, Washington 
PRECONCEPTUAL DESIGN REPORT

\section{K BASINS SLUDGE REMOVAL SLUDGE PRETREATMENT SYSTEM \\ Work Order E33937}

Prepared for

DE\&S Hanford, Inc.

Richland, Washington

Prepared by

Fluor Daniel Northwest

Richland, Washington

Fluor Daniel Northwest
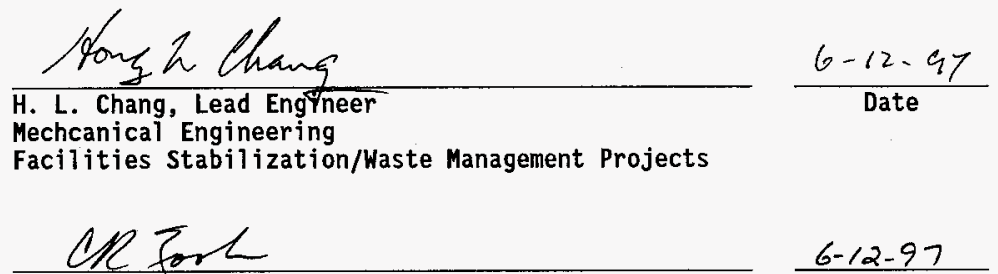

C. R. Zook. Task Manager

$6-12-97$

Mechanical Engineering

Date

Facilities Stabilization/Waste Management Projects

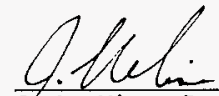

7. L. Wise, Project Manager

Spent Nuclear Fuel Projects

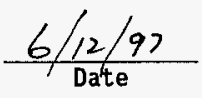




\section{TABLE OF CONTENTS}

Page

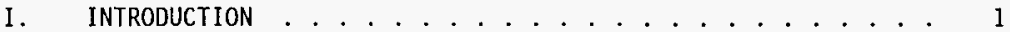

II. SUMMARY . . . . . . . . . . . . . . . . . 2

III. JUSTIFICATION . . . . . . . . . . . . . . . . 2

IV. DESCRIPTION OF PROJECT SCOPE ................ . . 3

A. BUILDINGS (501) . . . . . . . . . . . . . . . . . . . . . 3

B. OTHER STRUCTURES $(550)$. . . . . . . . . . . . . . 3

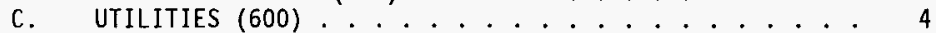

D. SPECIAL EQUIPMENT AND PROCESS SYSTEMS $(700) \cdot \cdots \cdots$

E. STANDARD EQUIPMENT (710 THROUGH 799) . . . . . . . . 20

F. OTHER PROJECT COSTS (900) ............ 20

G. DESIGN COMPLIANCE ............. 20

V. METHODS OF PERFORMANCE ........................ 20

VI. REQUIREMENTS AND ASSESSMENTS ............... 21

A. SAFEGUARDS AND SECURITY ................ 21

B. HEALTH AND SAFETY ................ . 21

C. DECONTAMINATION AND DECOMMISSIONING . . . . . . . . . . 21

D. PROVISIONS FOR FALLOUT SHELTERS . . . . . . . . . . . . 22

E. MAINTENANCE AND OPERATION REQUIREMENTS . . . . . . . 22

F. AUTOMATED DATA PROCESSING EQUIPMENT . . . . . . . . 22

G. QUALITY ASSURANCE AND SAFETY CLASSIFICATION . . . . . . 22

H. ENVIRONMENTAL COMPLIANCE . . . . . . . . . . . . 23

I. PERMITS . . . . . . . . . . . . . . . 23

VII. IDENTIFICATION AND ANALYSIS OF UNCERTAINTIES . . . . . . . 23

A. CIVIL/STRUCTURAL .................... . . . . . 23

B. SLUDGE PRETREATMENT PROCESS ............. 23

C. HVAC/STACK . . . . . . . . . . . . . . . . 26

D. ELECTRICAL .................... . . 26

E. INSTRUMENTATION AND CONTROLS ......... 27

VIII. REFERENCES . . . . . . . . . . . . . . 27

A. DOCUMENTS . . . . . . . . . . . . . . . 27

B. CORRESPONDENCE ................. 28

\section{APPENDICES}

Appendix A: Cost Estimate Appendix B: Equipment List Appendix $C$ : Sketches 


\section{ABBREVIATIONS}

$\begin{array}{ll}\text { ALARA } & \text { as low as reasonably achievable } \\ \text { ANSI } & \text { American National Standards Institute } \\ \text { ASME } & \text { American Society of Mechanical Engineers } \\ \text { CFR } & \text { Code of Federal Regulations } \\ \text { CVD } & \text { cold vacuum drying } \\ \text { DST } & \text { double-shell tank } \\ \text { HEPA } & \text { high efficiency particulate air (filter) } \\ \text { HLAN } & \text { Hanford local area network } \\ \text { HVAC } & \text { heating, ventilating, and air conditioning } \\ \text { IEEE } & \text { Institute of Electrical and Electronic Engineers } \\ \text { ISA } & \text { Instrument Society of America } \\ \text { PC } & \text { personal computer } \\ \text { PCB } & \text { polychlorinated biphenyls } \\ \text { PLC } & \text { programmable logic controller } \\ \text { PUREX } & \text { Plutonium Uranium Extraction (facility) } \\ \text { SNF } & \text { Spent Nuclear Fuel } \\ \text { TBD } & \text { to be determined } \\ \text { TWRS } & \text { Tank Waste Remediation System } \\ \text { WAC } & \text { Washington Administrative Code }\end{array}$




\title{
PRECONCEPTUAL DESIGN REPORT
}

\section{K BASINS SLUDGE REMOVAL SLUDGE PRETREATMENT SYSTEM}

\author{
Work Order E33937
}

\section{INTRODUCTION}

The Spent Nuclear Fuels Program is in the process of planning activities to remove spent nuclear fuel and other materials from the 100-K Basins as a remediation effort for clean closure. The $105 \mathrm{~K}$-East and K-West Basins store spent fuel, sludge, and debris. Sludge has accumulated in the $100 \mathrm{~K}$ Basins as a result of fuel oxidation and a slight amount of general debris being deposited, by settling, in the basin water.

The ultimate intent in removing the sludge and fuel is to eliminate the environmental risk posed by storing fuel at the $K$ Basins. The task for this project is to disposition specific constituents of sludge (metallic fuel) to produce a product stream through a pretreatment process that will meet the requirements, including a final particle size acceptable to the Tank Waste Remediation System (TWRS).

The purpose of this task is to develop a preconceptual design package for the $\mathrm{K}$ Basin sludge pretreatment system. The process equipment/system is at a preconceptual stage, as shown in sketch ES-SNF-01, while a more refined process system and material/energy balances are ongoing (all sketches are shown in Appendix $\mathrm{C}$ ). Thus, the overall process and associated equipment have been conservatively selected and sized, respectively, to establish the cost basis and equipment layout as shown in sketches ES-SNF-02 through 08.

The sludge pretreatment system is scheduled to be in operation beginning September 30, 2000, and finishing August 30, 2001. 


\section{SUMMARY}

The sludge pretreatment system will treat up to 68 cubic meters $(18,000 \mathrm{gal})$ of as-settled sludge beginning September 30,2000 , and finishing August 30, 2001.

The sludge pretreatment system is based on the process diagrams as recommended in Alternatives 1 and 8 or 9 of "Evaluation to Disposition Components of $K$ Basin Fuel Sludge," HNF-SD-SNF-ES-024, Rev. 0 (Papp 1997). Alternative 1 is the process that includes uranium dissolution with nitric acid and Alternative 8 is a polychlorinated biphenyls (PCB) extraction process with hexane. Alternative 9 is the PCB destruction process with hydrogen peroxide.

The $\mathrm{K}$ Basins sludge removal sludge pretreatment system is a Spent Nuclear Fuel (SNF) subproject. The total estimated project costs for installation of the sludge pretreatment system, not including site costs and other project costs, are:
Project Cost
$\$ 10,250,000$
Contingency $(41 \%)$
$\$ 4,280,000$
Total Dollars
$\$ 14,530,000$

\section{JUSTIFICATION}

WHC-SD-SNF-SP-001, Rev. O (Alderman 1995) documents the preferred path forward alternative for $\mathrm{K}$ Basin sludge removal. The TWRS double-shell tank (DST) system is currently permitted as a treatment, storage, and disposal facility pursuant to Washington Administrative Code (WAC) 173-303. The TWRS conducted an initial feasibility study, based on preliminary sludge characterization data, to determine if the sludge could be accepted into the DST system. The study concluded that the data did not indicate chemical compatibility problems with the waste stored in the prospective receiver DSTs; however, further evaluation is required before a definitive conclusion can be reached (Fowler 1995).

A waste compatibility assessment was performed (Wiemers 1996). The assessment recommends accepting the $\mathrm{K}$ Basin sludge waste stream into Tank 241-AW-105 following satisfactory disposition of the identified issues (Bason 1996). 
Based on the TWRS compatibility, Westinghouse Hanford Company performed a technical assessment of the TWRS criteria and recommended that the sludge be dispositioned at TWRS (Wiemers 1996). The TWRS criteria for the sludge acceptance was incorporated into the project Functional Design Criteria.

The current strategy for sludge removal reflects change request SNF-96067, "Resolution of Just-in-time Sludge Removal and Sludge Storage to IWTS." This change request documents the decision to remove sludge from $\mathrm{K}$ Basin to TWRS after the fuel has been removed. The sludge removal milestone of August 30, 2001, is supported by this strategy.

\section{DESCRIPTION OF PROJECT SCOPE}

\section{A. BUILDINGS (501)}

There are no significant modifications to the existing $105 \mathrm{~K}$ Buildings or to the Cold Vacuum Drying (CVD) Building. There will be electrical service connections to two electrical panels to serve the sludge processing system. There will be no modifications to the existing structures with the exception of seismic tie-downs into the existing concrete floor to secure the containers and skids.

\section{B. OTHER STRUCTURES (550)}

There will be no new permanent structures provided under this project. The sludge pretreatment system will be mounted on six separate skids. The skid plans and sections are shown on sketches ES-SNF-03, Skid 1; ES-SNF-04, Skid 2; ES-SNF-05, Skid 3; ES-SNF-06, Skid 4; ES-SNF-07, Skid 5; ES-SNF-08, Skid 6.

Two large shipping containers will be utilized to house the primary process equipment (Skid 1) and the offgas equipment (Skid 2). The containers will be refrigerator type with insulated walls, roof, floor, and doors to at least an $R 15$ value of conduction resistance. The remaining equipment will be unenclosed and skid-mounted. Only the stack monitor system and the control/electrical station will be enclosed in prefabricated walk-in type housings. The skids are designed to be self-contained modular units that can be assembled and arranged in different configurations to suit the site. The basis for 
this report assumes that Skids 1,2 , and 6 are located within the CVD or $105 \mathrm{~K}$ Building and are subject to the environment of the basin interior and not outside design conditions. Skid 5 chemical storage, Skid 3 stack/monitoring and Skid 4 cooling tower units are all outside. The skids will be located as close as possible to each other to simplify the interconnection of piping, ductwork, and electrical and control cables, and to allow easy operation and maintenance of the process and equipment.

Skids located outside will be on concrete pads. All skids will be seismically restrained. Skids 1,2 , and 6 (inside location) will be restrained using 3/4-in. diameter wedge type expansion anchors. Skids 3,4 , and 5 (outside location) will be restrained using buried concrete tie-down blocks (similar to FDNW Practice 134.210.4050, Mobile Office Installation Details, Sheet 4). Skid 5 will be provided with a dike as a secondary containment.

The storage containers, skids, equipment, and piping will be designed and analyzed in accordance with the natural phenomena loading criteria of DOE Order 6430.1A and GD-LOAD-01 (ICFKH 1996). The loading of components and equipment will be a function of the safety designation identified in the project safety assessment.

\section{UTILITIES (600)}

\section{Electrical Services}

The utilities to service the sludge pretreatment located outside the building will be extended from the CVD Building or the $105 \mathrm{~K}$ Building electrical system and will not require any additional outside services.

\section{Flush Water}

The sludge pretreatment system is intended to be operate remotely but will be provided with a hand-contact operable capability for maintenance. Water flushing will be required prior to a hand-contact operation. A flanged pipe connection with an isolation valve will be provided on the strategic location of the process piping system for flushing capability of the sludge pretreatment system. A booster pump may be required to boost the water to at least $2.1 \mathrm{~m} / \mathrm{s}$ at $590 \mathrm{kPa}$ 
( $7 \mathrm{ft} / \mathrm{sec}$ at $85 \mathrm{psig}$ ) for effective flushing. Backflow preventers will be installed near each interface with the sludge piping. With the exception of the vent and drain valves on the sludge piping, the flush water valves are remotely operated from the programmable controller console in the control room. The quantity and location of the flush connections will be finalized during definitive design.

\section{Make-up Water}

Make-up water will be required for the process system, cooling tower, and cooling circuit service.

\section{Drains}

Drainage accommodations for draining the cooling tower will be provided. If existing site drainage (storm drainage) is not suitable or available, pumper trucks will be utilized for removal of nonprocess water.

\section{SPECIAL EQUIPMENT AND PROCESS SYSTEMS (700)}

\section{Sludge Pretreatment Process}

The sludge pretreatment process system is based on the process diagrams as recommended in Alternatives 1 and 8 or 9 of document HNF-SA-SNF-ES-024, Rev. O (Papp 1997). The system will be designed to be operated in a batch process. Alternative 1 provides for the dissolution of metal components and associated oxides, in a nitric acid bath, for subsequent precipitation of solids with concentrated sodium hydroxide. Alternative 8 provides for a solvent extraction of PCBs, and Alternative 9 provides for PCB destruction.

\section{- Dissolution}

Dissolution of the fuel is achieved with nitric acid in a $10 \mathrm{M}$ concentration. The dissolution process will require some temperature control provided by closed heating and cooling loops. The inventory charged to the dissolver is scaled so that criticality is not a concern. 
HNF-SD-SNF-PCR-002, Rev. 0

The dissolver solution is processed on a batch-wise basis for the purpose of inventory control.

- Hexane Extraction of PCBs or Hydrogen Peroxide Destruction of PCBs.

A hexane wash process is designed to remove PCBs from the sludge solids. This process also requires identifying a PCB disposal path. An alternative approach may be to destroy the PCB using hydrogen peroxide.

\section{- Precipitation}

Precipitation of the dissolver solution is achieved by introducing sodium hydroxide into the solution. Some initial adjustments may be made to the concentration of the dissolver solution before caustic addition.

Dissolution of the sludge in the nitric acid and sodium hydroxide processes will result in insoluble solids and a solution bearing hydroxide. Insoluble solids may include sand and pieces of rock, as well as small pieces of cladding. Very small pieces of fractured resin may also be present. These solids will be filtered out of the process.

\section{- $\quad$ Adjustment}

Finally, a last adjustment is made before transfer for disposal. The intent of this step is to create a solution suitable for transfer and disposal meeting TWRS acceptance standards related to $\mathrm{pH}$, particle size and concentration. Recycle solutions may be introduced in this step for final dilution of the product stream thus maximizing the closed loop concept for operations.

\section{- Offgas System}

A ventilation system will contain, route, and treat all chemically-generated process offgas, as well as provide containment and ventilation for all vessels not involved directly in the process (storage tanks, etc.). The 
pretreatment portion of the ventilation system will reduce ammonia and nitrogen oxide concentrations in the offgas during chemical processing activities. A high efficiency particulate air (HEPA) filtration system will remove radioactive nuclides in the air stream. Nitrogen oxides will be recovered as nitric acid to ensure that gaseous emission limits are not exceeded. The recovered nitric acid will be reused in the chemical processing portion of the system to reduce chemical usage requirements. This system will also provide for the monitoring of radionuclides. The offgas system will minimize hazardous gaseous discharges to the environment.

- The equipment will be designed to criteria for natural phenomena so that the system can be maintained in a safe status without undue risk to public health and safety. The sludge pretreatment systems are not required to operate during or immediately following a safe shutdown earthquake.

\section{Equipment Design Features}

\section{- Location for the Sludge Pretreatment System}

The sludge pretreatment system will be designed to be removable in skids for locating to either the $105 \mathrm{KE}$ Building or the CVD Building.

A building grounding grid system is available within the proposed locations of the skids.

\section{- $\quad$ Skids}

The design concept is that the entire sludge pretreatment system will be installed in several skids:

Skid 1: Process equipment that will be installed inside the existing building. Skid 1 will be provided with radiation shielding.

- $\quad$ Skid 2: Offgas system located inside or outside the existing building, including nitric acid 
HNF-SD-SNF-PCR-002, Rev. 0

recovery and offgas treatment systems. Skid 2 will be provided with radiation shielding.

Skid 3: Stack and stack monitor system located outside the existing building in an enclosed prefab walk-in type housing.

Skid 4: Cooling tower, located outside the existing building.

Skid 5: Chemical feed system located outside the existing building.

Skid 6: Control station and electrical panels, located inside the existing building in an enclosed prefab walk-in type housing.

Inter-connection pipe between the skids will be provided with an encasement pipe for leakage containment. Both ends of the encasement pipe will be provided with flanges for removal/separation of the skids prior to locating the skids to either area.

The skid concept is to accommodate moving the sludge pretreatment process system to either location.

- Sample Points

Sample points will be provided at strategic locations in the process lines, as shown on sketch ES-SNF-01, to monitor the characteristic of the process stream. Typically, the sample line coming off from the process line penetrates the shield wall to the outside of the wall to the sample pot in a contained sample hood. A remotely-operated valve operated manually in the control station will perform the sample-taking operation.

\section{Radiation Shielding}

Removal shielding blocks will be placed over the skids to provide radiation shielding. The design objective for external exposure for the sludge pretreatment process shall be that no individual worker will receive an annual dose equivalent in 
HNF-SD-SNF-PCR-002, Rev. 0

excess of $0.5 \mathrm{rem} /$ year from all sources based on WHC-SD-GN-DGS-30011 (Evans 1994). A final shielding analysis based on $\mathrm{K}$ Basin sludge characterization data will be performed during definitive design.

Shielding material in this report is based on steel, but could be other types of materials such as concrete or lead. Final shielding material determination will be made during definitive design, based on cost, space availability and delivery.

\section{Valves}

- For in-line isolation of the sludge transfer lines and flush water piping connections to the sludge lines, pneumatically or electric (via electric solenoid) motoroperated valves with mounted limit switches and position switches will be used. The solenoids will be mounted above the floor level on a panel together with the dedicated pressure regulators for the respective air supply lines, and the pneumatic lines will be routed to the submerged valve operator. Position switches will provide local panel and programmable logic controller (PLC) input.

Motor-operated valves (Electric Actuators, $120 \mathrm{Vac}$ ) will be used in the process where a minimal amount of radiation is present, while pneumatic-operated valves will handle operation in the high radiation, heavily shielded, separations processing area. Valves in general will be failed closed type.

The valve type will be determined during definitive design based on a survey of the available valves in the industry that meet material compatibility criteria, and suitability of handling the sludge.

\section{- Backflow Preventer}

For preventing backflow, a WAC-approved backflow preventer will be installed in each flush line. The backflow preventers are comprised of two in-line check valves with manually operated ball valves at each end. 
HNF-SD-SNF-PCR-002, Rev. 0

A differential relief valve between the check valves diverts reverse flow that may leak past the first check valve. Further design development is required to collect potential liquid flow from the submerged backflow preventers.

\section{Pumps}

The type of pump will be selected based on factors such as explosion-proof requirements, power sources, solid particle and size distribution, radiation level, chemical compatibility, etc. The following pumps will be used in this project:

\section{- $\quad$ Sludge Pumps}

The type of pump selected for sludge transfer shall be capable of handling the $20-30 \%$ sludge, particle size up to $6.4 \mathrm{~mm}(1 / 4 \mathrm{in}$.) diameter, fluid characteristics and radiation level. The pump is shown in the drawing as an electric motor-driven pump; however, the final selection will be made during definitive design based on the above criteria.

The sludge pump in the sludge pretreatment system consists of pumps transferring: dissolver sludge, $\mathrm{pH}$ adjustment tank sludge and rework sludge. To prevent the downtime due to the system slogging/washing requirement, a backup pump for redundancy is provided.

\section{- $\quad$ Chemical Feed Pumps}

Nitric acid and sodium hydroxide feed pumps will be selected for metering service. These pumps will be located outdoors in a nonradioactive environment.

The Hexane solution pump will be an air-operated diaphragm type due to the volatile property of this chemical. 
- Other Pumps

There are other pumps that are not handling sludge, but may be radioactive with acidic or caustic fluids. The pump types will be selected during definitive design to ensure that they are adequate for the intended services.

- $\quad$ Mixers

Variable speed control will be required for the mixers only.

\section{Chemical Addition Tanks}

Chemical addition tanks consists of:

- One 19000 L (5000 gal) 50\% nitric acid tank

- One 9500 L (2500 gal) $50 \%$ sodium hydroxide tank

- Hydrogen peroxide tank

- Hexane tank

These tanks will be mounted on a common skid and located outside the building. The perimeter of the skid will be walled (diked) to act as secondary containment for spillage. The tanks will be insulated and equipped with heat tracing for freeze protection.

\section{Offgas System}

The offgas system consists of the equipment briefly described below. The equipment is listed in sequential order as found in the actual offgas system, from the start of the system to the end. The estimated equipment sizes are shown in Appendix B.

- One nitric acid and ammonia recovery condenser (downstream of dissolver) will be required. The condenser will be a vertically-mounted shell/tube heat exchanger, sized to cool $235 \mathrm{~L} / \mathrm{s}(500 \mathrm{cfm})$ dissolver offgas from $90^{\circ} \mathrm{C}$ to $35^{\circ} \mathrm{C}$, and will require 
approximately $15.7 \mathrm{~kW}(53,700 \mathrm{btu} / \mathrm{hr})$ in cooling capacity.

- One ammonia scrubber will be located downstream of the condenser. The scrubber will have approximately three counter current stages with water. The actual flowrate will be determined through laboratory scale work and process optimization once definitive mass balances have been established for the entire process.

- After leaving the ammonia scrubber, the process offgas then enters two heaters staged in series (just upstream of the silver reactor). These heaters are required to keep the gas stream above it's dew point and to enhance iodine adsorption in the silver reactor. The two heaters will be high temperature air duct heaters, each having a $30 \mathrm{~kW}$ estimated capacity.

- The heated offgas will enter a silver reactor. The reactor will have an arrangement of single or multiple packed beds of silver-nitrate coated berl saddles (or other appropriate type of packing).

- Once the offgas exits the silver reactor, it enters deep bed filters.

- From the deep bed filters, the offgas then enters two acid absorbers placed in series. The gas enters near the bottom of the first absorber and flows upward, exiting at the top. The gas then enters near the bottom of the second absorber and also exits near the top. The gas is contacted with a counter-current flow of water and a dilute nitric scrub solution that has already passed through the absorber. The dilute scrub solution routed back to the absorbers will contain a small amount of hydrogen peroxide. This hydrogen peroxide bleed stream will help ensure any nitrous acid $\left(\mathrm{HNO}_{2}\right)$ is oxidized to form nitric acid $\left(\mathrm{HNO}_{3}\right)$.

The acid absorbers will contain about three countercurrent stages. 
The dilute nitric scrub solution from the absorbers will be routed to a nitric acid fractionator. The purpose of the fractionator is to bring the concentration of the recovered nitric acid from an estimated 25 weight percent nitric acid concentration to about 50 weight percent nitric acid. The $\mathbf{5 0}$ weight percent recovered nitric acid will then be routed back for reuse in the process. The fractionator is basically a distillation column combined with a reboiler. The fractionator performs a binary separation of nitric acid and water (distills off water from the nitric acid, increasing the nitric concentration to the desired weight percent).

The nitric acid fractionator column will consist of about four to five theoretical stages.

- The offgas stream from the absorbers will be routed through a condenser to remove most of the moisture. The offgas will then be routed through a HEPA filtration system. The condenser will be a shell/tube type heat exchanger. The actual heat load requirements and the size of the condenser will be determined as part of the subsequent conceptual design activities.

\section{Piping}

The sludge pretreatment system will be designed to handle flow capacities of up to $3 \mathrm{~L} / \mathrm{s}(50 \mathrm{gpm})$ with minimum flow velocity of $2.1 \mathrm{~m} / \mathrm{s}(7 \mathrm{ft} / \mathrm{sec})$.

The system will be provided with flush water for removing settled solids or recovering from blockage.

The piping material will be compatible with the characteristics of the $K$ Basins sludge. The piping connections will be self sealing and have no drip. There will be quick disconnects at the transportation vessel interface. Connection design wili accommodate the use of glovebags during the offload process. A male coupler will be provided for connection to the sludge transportation system.

The sludge pretreatment system piping will comply with ASME B31.3, Process Piping. 
HNF-SD-SNF-PCR-002, Rev. 0

Piping will be designed for the following fluid properties:

\begin{tabular}{|c|c|}
\hline Viscosity: & $\begin{array}{l}\text { Will be decided during } \\
\text { conceptual design }\end{array}$ \\
\hline Maxi & $690 \mathrm{bPa}(100 \mathrm{psig})$ \\
\hline Minimum flow velocity: & $2.1 \mathrm{~m} / \mathrm{s}(7 \mathrm{ft} / \mathrm{sec})$ \\
\hline
\end{tabular}

9. Heating, Ventilating, and Air Conditioning (HVAC)

The HVAC systems include the offgas nonprocess components (HEPA filters, heaters, stack, exhaust fans and ductwork) and air conditioning systems for all the contained areas. Key criteria are the maintenance of suitable negative pressures in radiation controlled areas, comfort conditioning, and required ventilation air for occupied spaces.

The offgas process air flow is estimated to be $235 \mathrm{~L} / \mathrm{s}(500$ $\mathrm{cfm})$. An additional $140 \mathrm{~L} / \mathrm{s}(300 \mathrm{cfm})$ of makeup air is estimated to be needed for space conditioning. Total infiltration into both the process container and the offgas container is estimated to be $47 \mathrm{~L} / \mathrm{s}(100 \mathrm{cfm})$. Therefore, the total exhaust out the stack is $425 \mathrm{~L} / \mathrm{s}(900 \mathrm{cfm})$. The stack and exhaust fans are sized for $470 \mathrm{~L} / \mathrm{s}(1,000 \mathrm{cfm})$. Normal offgas contributions during sludge processing are shown in Table I.

Air is introduced into the primary process area (Skid 1) and the secondary containment area (Skid 2) via filtered air inlets on the roof of each module due to the negative pressures created in each module. Two exhaust blowers (one standby) draws air from each module, including bleed-off air flows through the three main reaction vessels, plus the fractionator in Skid 2.

The air-handling units for Skids 1 and 2 provide room air conditioning to accommodate process control as well as comfort for maintenance personnel during maintenance and operations periods.

Skid 1 is protected accordingly with HEPA filtration and the required safety and control features. Since the design life of the facilities is 1 year, the HEPA filters are disposable and sized to last for the life cycle. 
HNF-SD-SNF-PCR-002, Rev. 0

TABLE I

\begin{tabular}{|ll|}
\hline Dissolver & $140 \mathrm{~L} / \mathrm{s}(300 \mathrm{cfm})$ \\
pH Adjust & $36 \mathrm{~L} / \mathrm{s}(75 \mathrm{cfm})$ \\
\multicolumn{1}{|c}{ Rework Tank } & $36 \mathrm{~L} / \mathrm{s}(75 \mathrm{cfm})$ \\
Centrifuge (C-2) Vent & $23 \mathrm{~L} / \mathrm{s}(50 \mathrm{cfm})$ \\
Total Offgas & $235 \mathrm{~L} / \mathrm{s}(500 \mathrm{cfm})$ \\
& \\
Fractionator Vent & $24 \mathrm{~L} / \mathrm{s}(500 \mathrm{cfm})(\mathrm{recir})$ \\
Makeup Air: & \\
\multicolumn{1}{|c}{ AHU-1 } & $213 \mathrm{~L} / \mathrm{s}(450 \mathrm{cfm})$ \\
AHU-2 & $165 \mathrm{~L} / \mathrm{s}(350 \mathrm{cfm})$ \\
Infiltration: & $47 \mathrm{~L} / \mathrm{s}(100 \mathrm{cfm})$ \\
\multicolumn{1}{c}{ Total Stack Cap } & $425 \mathrm{~L} / \mathrm{s}(900 \mathrm{cfm})(\mathrm{size}$ for \\
& $470 \mathrm{~L} / \mathrm{s}$ or $1,000 \mathrm{cfm})$ \\
\hline
\end{tabular}

An HVAC control system will be provided to allow the air handling units, the stack exhaust fans, and motorized dampers to maintain a negative $(-62 \mathrm{~Pa}$ or $-0.25 \mathrm{in}$. $\mathrm{wg}$.) in the process containment area and a negative (-37 Pa or -0.15 in. wg.) in the offgas containment area.

The HVAC system will be monitored and controlled from the same central location as the batch processing.

Since the sludge pretreatment process will operate only 8 hours a day, an exhaust bypass is included to allow the stack exhaust to bypass the process units. During conceptual design, lowered exhaust flows should be considered during nonprocessing periods to conserve energy and filter life.

Skids 3 and 6 have small occupied cubicles which will be heated and cooled with wall-mounted air-conditioning units. The electrical equipment room in Skid 6 will have an exhaust fan to keep temperatures from exceeding the operating limits of the equipment. 
The exhaust stack will be sectional and made of fiberglass to allow the stack to be disassembled and moved from one site to the other.

The exhaust stack monitoring station will be factory assembled as a complete operation unit. It will be shipped to the site for mounting on the skid, needing only electrical and probe connections.

\section{Electrical}

The electrical systems will comply with the National Electrical Code (NFPA 70), ANSI C2, National Electrical Safety Code; and applicable sections of DOE Order 6430.1A.

The following electrical modifications are required to provide the 3-phase, 3-wire electrical power service to the sludge removal pretreatment system:

- A new 200. A feeder breaker will be installed at the existing switchboard "105KE SWBD 7F" located outside at a short distance from the transfer area.

- A new $200 \mathrm{~A}$ feeder breaker will be installed at the existing $105 \mathrm{KW}$ switchgear located in electrical equipment room 1.

The electrical power distribution system will serve the following sludge removal pretreatment system electrical loads:

Two rework tank transfer pumps

A rework tank agitator

Two stack exhaust fans

An electric hot water heater

A hot water circulating pump

Two acid fractionater pumps

Two electric duct heaters [2 stages]

An electric duct heater

Two centrifuges

A cooling tower pump

Two cooling tower fans

A pH adjustment tank agitator

Two pH adjustment transfer pumps 
A water solution tank pump

A dissolver tank agitator

Two dissolver fluid transfer pumps

Two dissolver condensate pumps

A nitric acid feed pump

Four dilute acid pumps

Two air-handling units $\mathrm{AHU}-1$ and $\mathrm{AHU}-2$

A nitric acid recovery pump

Two heat pumps

A $480 \mathrm{~V}-208 \mathrm{~V} / 120 \mathrm{~V}$ dry type transformer and panelboard will be provided for the following electrical loads:

An unteruptable power supply and an output panelboard for the instrumentation and control equipment.

A lot tank heat tracing (as required).

A lot pipe heat tracing (as required).

A lot lighting/receptacle (as required).

An air conditioner unit and ventilation exhaust fan for Skid 5 .

A stack monitor equipment and air conditioner unit for Skid 3 .

No equipment or materials, prior to installation by this project, will contain mercury or polychlorinated biphenyls.

Local safety disconnect switches will be provided near equipment served as required by NFPA 70 .

Electrical installation inside the skid containing the hexane tank will be as required by the NFPA 70, Article 500 thazardous classified location).

A motor control center, dry type transformer, and panelboard will be installed in the electrical equipment room section of Skid 6.

No emergency backup electrical power will be provided.

Heat and radiation-resistant cables will be used inside skids with radioactive environments. 
Electrical circuits, exposed noncurrent metal carrying metal parts of electrical equipment, and the skids metal structures will be grounded in accordance with provisions of the NFPA 70.

\section{Instrumentation and Controls}

The $\mathrm{K}$ Basin sludge pretreatment system, or sludge removal automated control system, will be a PLC-based system connected to a personal computer ( $\mathrm{PC}$ ) workstation that will remotely monitor and operate the process outside the radiation contaminated area to reduce the potential of radiation exposure to operations personnel during operation of the pretreatment process. The PC workstations operating system will be Microsoft Windows NT or Windows 95, with a human-machine-interface software package such as the Wonderware Intouch, Intellution FIX 32, or Ci Technologies CiTect handling the operator interface, alarm processing, batch processing and other functions necessary for flushing and operations recovery.

The PLC will be housed in an enclosure that will be located in a heated and ventilated skid-mounted control room. The skid-mounted control room will be located some distance away from the processing modules and will ease the accessibility and maintenance to the PLC. To keep the control room skid portable, quick disconnect instrumentation field wiring hardware will be designed into the skid.

One source of $120 \mathrm{Vac}$ power with uninterruptible power supply will be provided to the PLC enclosure, then distributed throughout the unit. Prewiring of the terminal strips to the PLC modules and other instrumentation equipment inside the PLC enclosure will be done at the control system vendors facility.

A printer will be connected to the workstation to provide hard copy printouts of alarm conditions, report generation and historical trending. A second personal computer will be provided for word processing, HLAN connection and operational support.

Instrumentation will include the following:

- Tank level sensors

- Temperature sensors

- Pressure sensors 
- Flow measurements (flow monitoring of sludge, water, and offgas)

- Leak detection of process module sumps and transfer encasement lines

- Remotely-operated motor-actuated valves

- Remotely-operated pumps (variable speed, start/stop operation, interlocks)

- Remotely-operated mixers (variable speed, start/stop operation, interlocks)

- $\quad \mathrm{pH}$ monitoring

- Radiation detection and alarms

- Criticality alarms

- Combustible gas monitoring and alarms

The exhaust stack will be monitored via a self-contained monitoring module located on Skid 3. The stack exhaust will be continuously sampled and monitored for $\mathrm{NO}_{\mathbf{X}}$, Hydrocarbons, particulate and air flow.

Radiation and criticality alarms will be required. Radiation monitoring will required for the output of the stack and for the final effluent going to disposal. Also, radiation monitoring will be required at the input feed to the pretreatment process.

A secondary containment will be required in the process modules. Along with containment, confinement control will be required using negative air pressure flow.

Instrumentation will conform to the NFPA 70, applicable sections of DOE Order 6430.1A, and applicable ANSI, Institute of Electrical and Electronics Engineers (IEEE) and Instrument Society of America (ISA) standards. 


\section{E. STANDARD EQUIPMENT (710 THROUGH 799)}

A dedicated compressed air system will be provided for servicing the air-operated diaphragm pumps and the pneumatic operating valves. The air compressor will be installed in a skid outside the building.

\section{F. OTHER PROJECT COSTS (900)}

\section{Construction Support}

To support onsite construction in the K Basin, the job control system will be utilized to authorize work. The job control system work packages will be generated, reviewed and approved, and issued to the construction crews for implementation. In addition, radiological control technicians will be utilized to support work in radiation zones. Operations will, as required, provide engineering and nuclear operators support as work progresses.

\section{Start-up Support}

Upon completion of construction, an acceptance test and operational test will be conducted to verify construction adequacy and to address testing requirements. This will require operations engineers and maintenance to support these tests. An operational readiness review/assessment will be conducted to ensure that the system has met all requirements and that the operations group is adequately prepared to initiate transfer activities.

\section{G. DESIGN COMPLIANCE}

The latest edition/revision of all applicable codes, standards, and manuals will be used.

\section{METHODS OF PERFORMANCE}

The methods of performance will be addressed during definitive design. 


\section{REQUIREMENTS AND ASSESSMENTS}

\section{A. SAFEGUARDS AND SECURITY}

To be addressed during definitive design.

\section{B. HEALTH AND SAFETY}

Radiation exposure to workers will be minimized and radiation protection measures will comply with $10 \mathrm{CFR} 835$, Occupational Radiation Protection, as implemented by the Hanford Site Radiological Control Manual, HSRCM-1. Consideration will be given to Radiological Design Guide, WHC-SD-GN-DGS-30011.

Equipment will be designed so that no single failure of equipment will cause a loss of control that will result in an unrecoverable condition. Features will be provided that will facilitate placement of the equipment in the appropriate position to establish a safe configuration.

The system will be designed to permit routine maintenance activities with minimum operator exposure to hazardous or radioactive environments. ALARA practices will be used in all maintenance activities. The system will be designed to be operated and maintained in a radiation zone and operated under contaminated conditions.

Shielding design will include the ease of removal of shielding for subsequent removal of the transfer line at the end of the project, or whenever required.

The design objective for external exposure of the system will be that no individual worker will receive an annual dose equivalent in excess of 5 millisieverts $(0.5$ rem per year) from all sources.

\section{DECONTAMINATION AND DECOMMISSIONING}

Sludge pretreatment system piping and concrete shielding will be decontaminated to ALARA, decommissioned, and disposed. 


$$
\text { HNF-SD-SNF-PCR-002, Rev. } 0
$$

The sludge pretreatment system will include provisions for water flushing.

Decontamination and decommissioning will comply with DOE Order 6430.1A, Section 0205 and 1300-11, and DOE Order $5820.2 A$, Chapter $V$ requirements.

\section{PROVISIONS FOR FALLOUT SHELTERS}

There will be no provisions for fallout shelters as part of this project.

\section{E. MAINTENANCE AND OPERATION REOUIREMENTS}

The sludge pretreatment system will include features to allow for unplugging the transfer line.

The design life of the sludge pretreatment system will be 1 year. Design and material selection will include features that facilitate maintenance of the equipment and the facility (10 CFR 835.1002(d)).

Particular attention will be paid to minimization of liquid retention and ease of replacing valves, connectors, and any equipment in high or very high radiation areas.

Operation of the sludge pretreatment system will require $\mathrm{K}$ Basin operators and radiological control support.

\section{F. AUTOMATED DATA PROCESSING EQUIPMENT}

No new automated data processing/telecommunications equipment is required for this project.

\section{G. QUALITY ASSURANCE AND SAFETY CLASSIFICATION}

Quality assurance will be addressed during definitive design. The equipment/components of the system will be classified as safety significant. 


\section{H. ENVIRONMENTAL COMPLIANCE}

An environmental requirements checklist covering removal, transport, and storage of $\mathrm{K}$ Basin sludge has been prepared by Environmental Services (Tollefson 1995), through the SNF Regulatory Integration/Public Involvement group.

\section{PERMITS}

The performance contractor will provide all permits.

\section{IDENTIFICATION AND ANALYSIS OF UNCERTAINTIES}

A. CIVIL/STRUCTURAL

Siting inside skids is contingent upon the size of skids and the layout of available rooms inside the existing building that is chosen for pretreatment system location. Outside skid siting is contingent upon the interface with existing aboveground and below ground site features.

\section{B. SLUDGE PRETREATMENT PROCESS}

Some of the $\mathrm{K}$ Basin sludge pretreatment processes are undergoing laboratory testing to verify the validity of the recommended processes. This preconceptual design is based upon preliminary flowsheet configurations and data. Mass and heat balance data for a variety of process flow sheet values are not currently available. Where this is the case, assumed equipment sizes were used based strictly on engineering experience and judgement.

Optimization of equipment and of the process has not been done; these tasks are outside the scope of this preconceptual design. In most cases, process data for the various process streams was not available. Once the laboratory testing and flow sheet mass balance has been completed and all process parameters are known for the process streams, a conceptual design may be started and a more refined concept produced. 
- Type of Equipment

Process equipment optimization was not performed because it is beyond the scope of the preconceptual design. Offgas system equipment was chosen based on discussions with the process technical lead as well as what is depicted in the currently available flowsheet baseline. Absorption and recovery of nitric acid, for example, could potentially be accomplished using other technology than the simple water/gas absorption tower. This is especially true in the case of iodine absorption in the silver reactor.

The type of pumps and valves for handling the sludge will be evaluated in more detail during definitive design.

It is unknown if duct heaters with coils placed in the air stream will operate as intended without knowing if crystallization, for example, will accumulate on the coils.

The dissolver tower condenser, a vertical shell and tube type, may need to be specially fabricated. A vendor who provides these as a standard (although not necessarily off-the-shelf) could not be located in the time allotted to accomplish this task.

Details on the ventilation system and it's operation, need to be further developed. This includes consideration of utilizing a separate vessel, condenser, and process ventilation systems (all discharging into the same stack). Because of the vast differences in the required flowrate and vacuum in each of the systems, and the control requirements, it is recommended that ventilation for these systems be kept separate.

- Size of Equipment

As stated previously, the size of equipment, in most cases, is a very rough estimate based on limited information. In other cases, it is strictly an assumption which may or may not be valid. This is especially the case regarding the silver reactor, dissolver condenser, and nitric acid absorber condenser. The silver reactor has the best basis of the three, being based on the PUREX silver reactor and the relative process offgas it was required to accommodate. 
HNF-SD-SNF-PCR-002, Rev. 0

Another area of uncertainty is in the choice of the centrifuge. Because the nature of the equipment is susceptible to failure and its gravity feed requirement and above dissolver design (space limitations), further investigation into the appropriateness of the type/model chosen is required. Its overall size, configuration, as well as rotor/cake holding capacity may need to be refined as well. Development/design of the interface between it's discharge and the vessel it connects to below, as well as its venting capabilities, also needs to be addressed.

The dissolver, like the centrifuge, is a key piece of equipment in the process. Once all the processing parameters and control/measurement operation functions are fully defined, this piece of equipment should be reinvestigated.

Process optimization, when accomplished, will also potentially effect the size of tanks as well as other pieces of equipment.

In summary, all process related equipment cannot be effectively sized until the flow configuration and the mass/energy balance is completed.

\section{- Centrifuge/Filter}

There are two centrifuges and one filter provided in the process system for solids/liquid separation. The first centrifuge, located upstream of the dissolver is to separate the solids for discharging into the dissolver, the second centrifuge located upstream of the $\mathrm{pH}$ adjustment tank is to remove the excess water in the filter cake for drum disposal. The filter located upstream of the $\mathrm{pH}$ adjustment tank separates and delivers the slurry carrying smaller than $50 \mu \mathrm{m}$ particles to the $\mathrm{pH}$ adjustment tank and the larger particles to the second cer.:rifuge.

The centrifuges shown on sketch ES-SNF-01 are considered to be too large. There is a possibility that solids will overload and plug up the filter mesh. Further research of the centrifuge type is required.

Uncertainties regarding the equipment selection are the establishment of the characteristics of the slurry, particle size 
HNF-SD-SNF-PCR-002, Rev. 0

distribution, solid liquid ratio in the slurry, and total quantity of solids to be removed in the slurry. A conservative assumption will result in over-designing the equipment, an under-design will result in equipment being under sized, either way may render the equipment inoperative. A final selection of the equipment will require an in-depth study of the slurry characteristics and laboratory testing of different types of filters/centrifuges available on the market due to uncertainties.

- Offgas/NO $\mathrm{NO}_{\mathrm{X}}$ Control

Site limits require annual $\mathrm{NO}_{x}$ emissions of less than $36400 \mathrm{bg}$ ( 40 tons) per year. There are three widely used technologies for $\mathrm{NO}_{x}$ control in industry: selective catalytic reduction, selective non-catalytic reduction, and reburn (nonstoichiometric firing) process. Advances in $\mathrm{NO}_{X}$ treatment technologies have focused on optimizing the technologies and in combining these technologies with treatments for other pollutants. Some of these technologies involve treatment of $\mathrm{NO}_{X}, \mathrm{SO}_{X^{\prime}}$ and particulates and are smaller and less expensive than using separate systems for each treatment. Most of these technologies are under development but should be fairly advanced by the time the low-level vitrification facility begins operation.

The offgas $/ \mathrm{NO}_{x}$ control method for this project will be further evaluated prior to the definitive design.

\section{HVAC/STACK}

It is assumed that Skids 1, 2, and 6 will be located inside an enclosed heated and cooled building similar to the $105-\mathrm{K}$ Buildings. If these units are located outside, they should be roofed for solar protection and the air conditioning increased accordingly.

\section{ELECTRICAL}

Cable trays will be used instead of conduits for protection of wiring between the skids, if the skid locations are not too far apart. Multiconductor power cable suitable for installation in cable trays will be used instead of single individual wires installed in conduits. 


$$
\text { HNF-SD-SNF-PCR-002, Rev. } 0
$$

The proposed source of electrical power service (105KE "SWBD 7F" and $105 \mathrm{KW}$ " $480 \mathrm{~V}$ Switchgear") is acceptable with the K Basins cognizant engineering. It would have been an ideal situation, if $105 \mathrm{KW}$ has a switchboard location similar to 105KE "SWBD 7F".

The proposed source for electrical power applies to the $105 \mathrm{~K}$ Buildings only. It is assumed that the electrical power source for the CVD Building will be equally as convenient.

\section{E. INSTRUMENTATION AND CONTROLS}

Leak detection will be necessary on each process module sump and possibly transfer encasement lines.

The type of tank level sensor best suited for this work will be determined during conceptual design.

\section{REFERENCES}

A. DOCUMENTS

1. Papp, 1. G., March 1997, Evaluation to Disposition Components of $K$ Basin Fuel Sludge, HNF-SD-SNF-ES-024, Rev. O, Numatec Hanford Corporation.

2. Alderman, C. J. 1995, Westinghouse Hanford Company Recommended Strategy for $\mathrm{K}$ Basin Sludge Disposition, WHC-SD-SNF-SP-001, Rev. 0, Westinghouse Hanford Company.

3. Bason, R. F., 1996, Preliminary Acceptance Recommendation for KE Floor Sludge Waste, Internal Memo R. F. Bason to J. C. Fulton.

4. Evans, R. A. 1994, Radiological Design Guide, WHC-SD-GN-DGS-30011, Westinghouse Hanford Company.

5. Fowler, K. D., 1995, K Basin Sludge to TWRS: Transfer Feasibility, Internal Memo, Westinghouse Hanford Company. 
HNF-SD-SNF-PCR-002, Rev. 0

6. Precechtel, D. R., and M. J. Monthey, 1996, Functional Design Criteria for the $\mathrm{K}$ Basin Sludge Removal System, WHC-SD-SNF-FDC-004, Westinghouse Hanford Company.

7. FDNW Practice 134.210.4050, Mobile Office Installation Details, Sheet 4 .

8. DOE Order 6430.1A, General Design Criteria.

9. GC-LOAD-01 (ICFKH 1996), Design Load for Facilities.

10. SNF-96-067, Resolution of Just-in-Time Sludge Removal and Sludge Storage to IWTS.

11. Tollefson, K. S., 1995, Environmental Requirements Checklist for Removal, Transport, and Storage of $105 \mathrm{KE}$ and $\mathrm{KW}$ Basins Sludge, Internal Memo, 95-POC-036, Westinghouse Hanford Company, November 2, 1995.

\section{B. CORRESPONDENCE}

1. Letter of Instruction, DESH-9753917, Work Order E33937, Project A.13 - K Basins Sludge Removal Pretreatment Preconceptual Design, May 1, 1997.

2. 8M730-RAS-96-006, Letter from Criticality and Shielding to D. R. Precechtel, Dose Rates for Sludge Inside a Pipe, August 1996.

3. K. L. Pearce, Letter DESH-9752731, March 1997, Attachment $1, \mathrm{~K}$ Basins Sludge Inventory Determination and Values.

4. D. J. Trimble, Attachment to Letter, An Estimate of $\mathrm{K}$ West Basin Canister Sludge Inventory, January 1997.

5. Request for Approval of Second Revision of Memorandum of Understanding, Letter 9652070, Westinghouse Hanford Company, Richland, Washington, dated May 6, 1996.

6. M. J. Wiemers, Westinghouse Hanford Company, to E. D. Sellers, U. S. Department of Energy, Richland Operations Office, "Completion of Spent Nuclear Fuel Project Milestone S04-96-112," 9653704, August 30, 1996. 
HNF-SD-SNF-PCR-002, Rev. 0

\section{APPENDIX A}

Cost Estimate 
FLUOP. DANIEL NORTHWESY, INC. DUKE ENG]HEER ING

JOB NO. E33936/F3YC4F

FILE NO. YABZSADI
* * IEST - INTERACTIVE ESTIMAT:NG *

SLUDGE PRE-TREATMENT, K- BASINS;

FONHRO? - PROLECT COST SUMMARY
PAGE 1 OF 8

DATE 06/11/97 19:48:04

BY DEA, RW, LH

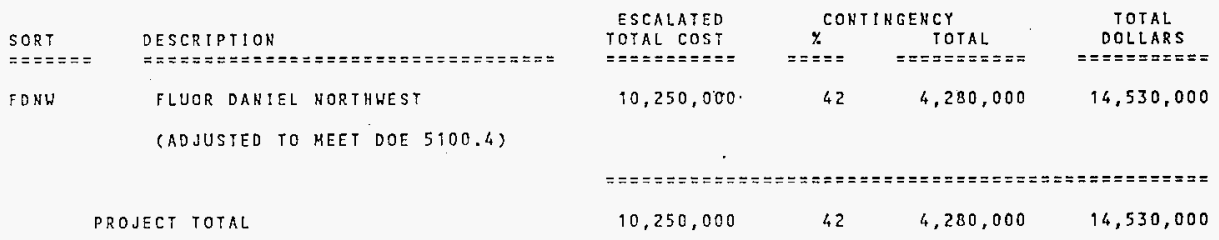

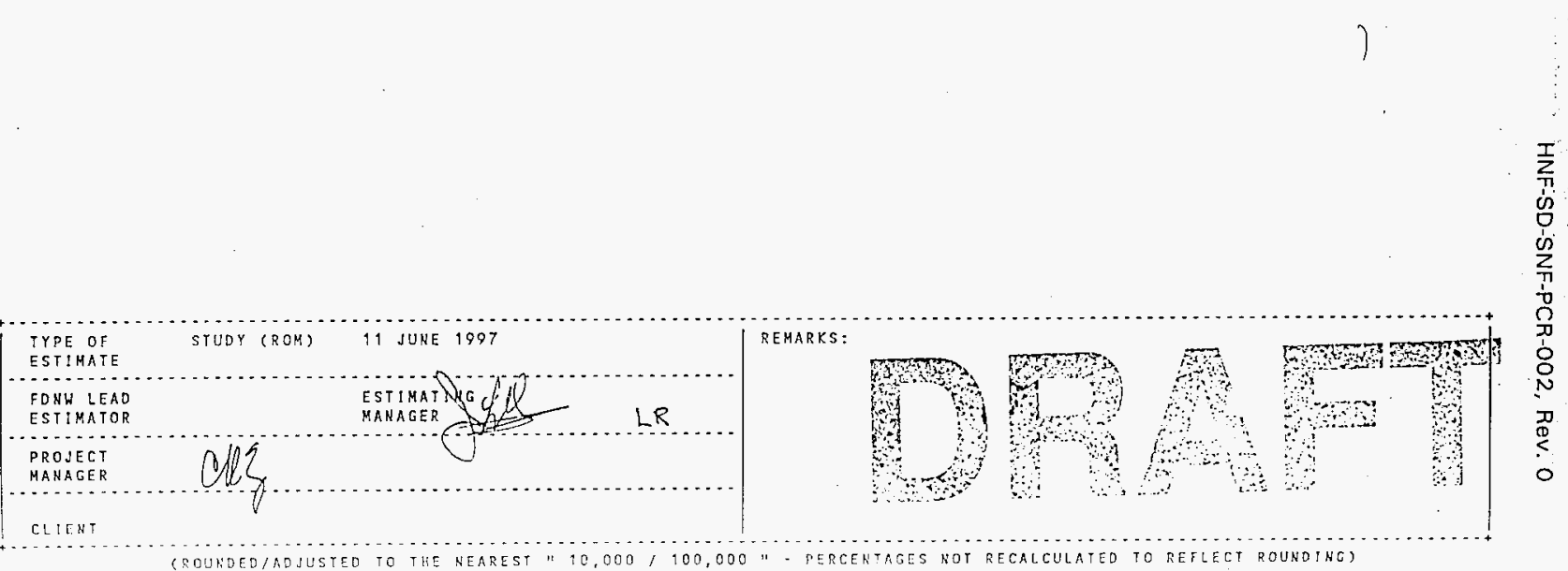


FLUOR DANIEL NORTHHEST, INC. DUKE ENCINEERING \& SERVICES

JOS NO E3 $336 /$ S Y

FILE NO. YABZSAD

WBS DESCRIPTION

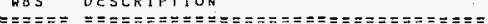

111100 DEFINITIVE DESIGN-CAT 1-ONSITE E/C SUBTOTAL 19 DEFINITIVE DESICN-CAT 1

SUBTOTAL 11 DEFINITIVE DESIGH

121000 ENGINEERING/INSPECTION-ONSITE E/C SUBTOTAL I21 ENGINEERING/INSPECTION-ONSI SURTOTAL 12 ENGIMEERING/INSPECTION

SUGTOTAL, ENGINEERING

220000 PROCUREMENT-O/C

SUBTOTAL 22 PROCUREMENT-O/C

SUBTOTAL 2 PROCUREMENT

320000 CONSTRUCT:ON-FIXED PRICE

SUBTOTAL 32 CONSTRUCTION-FIXEO PRICE

SUBTOTAL 3 CONSTRUCTION

PROJECT TOTAL
* * IEST * INTERACTIVE ESTIMATING * *

SLUDGE PRE-TREATMENT, K- BASINS;

FONWRO2 - WORK BREAKDOWN STRUCTURE (WBS) SUMMARY
PAGE 2 OF 8

DATE $06 / 11 / 97 \quad 11: 48: 08$

BY DEA, RH, LHR

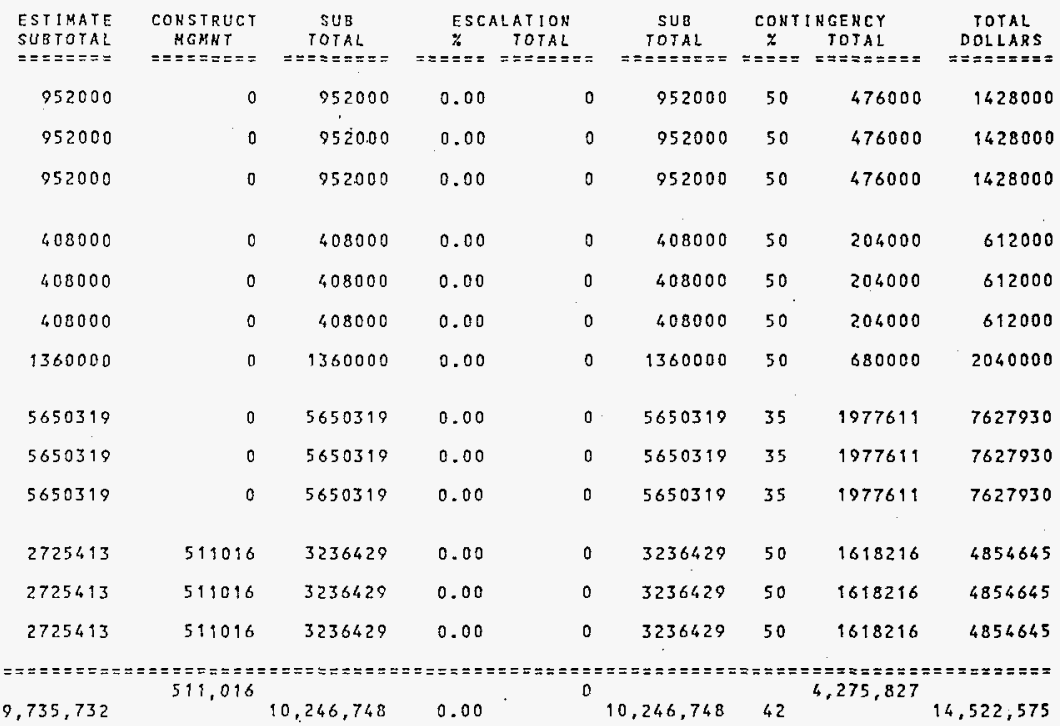


FLUOR DANIEL. NORTHWEST, INC.

DUKE ENGINEERING \& SERVICES

JOB NO. E33936/F3YC4F

FILE NO. YARZSADI

1. ESTIMATE PURPOSE

ORDER OF MAGNITUDE ESTIMATE: THIS ESTIMATE HILL TO BE USED FOR BUDGETING PURPOSES ONLY.

2. ESTIMATE TECHNICAL BASIS

A. THIS ESTIHATE HAS GEEN PREPARED FOR THE K-BASINS TEMPORARY SLUDGE PRETREATHENT PROJECT AS REQUESTED BY DE\&S HAHFORD, IHC.

B. A DESCRIPIION OF THE TECHNICAL SCOPE OF WORK MAY BE FOUND IN THE FOLLOHING REFERENCE DOCUMENTS:

LETTER OF INSTRUCTION (LOI) \#E33936.

REQUEST FOR ESTIMATE DATED 13 MAY 1997.

PRE-CONCEPTUAL DESIGN REPORT "SLUDGE PRE-TREATMENT FOR X-BASINS, DATED MAY 1997.

C. THIS EST M MATE ALSO UTILIZES A STANDARD FONW DEFINED CODE DF ACCOUNTS.

3. ESTIMATE METHODOLOGY

A. DIRECT COSTS:

A SPECIFIC NNALOCY TECHNIOUE AND EXPERT OPINION TECHNIOUE HAS BEEH UTILIZED IN THE PREPARAIION OF THIS ESTIMATE.

(1) CONSTRUCTION LABOR, MATERIAL AND EQUIPMENT UNITS HAVE BEEN ESTIMATED BASED UPON SIHILAR HORK ON OTHER PROJECTS. THE UNITS MAY HAVE BEEN FACTORED/ADJUSTED BY THE ESTIMATOR AS APPROPRIATE TO REFLECT INFLUENCES BY CONTRACT, HORK SITE, OR OTHER TOENTIFIED PROJECT OR SPECIAL CONDTTIONS.

SUBCOUTRACTOR DIRECT COSTS FOR DUKE ENGINEERING \& HANFDRD, IMC. HAYE BEEN PROVIDED BY FDHW PROJECT MANAGEMENT FOR INCLUSION INTO THIS ESTIMATE.

3. DIRECT COST FACTORS

(1) SALES TAX HAS BEEN APPLIED TO ALL MATERIALS AND EOUIPMENT PURCBASES AT $8 \%$

(5) CONTRACT ADMINISTRATION FACTOR OF $18.75 \%$ HAS BEEN APPLIED IO TRE DIRECT CONTRACT VALUE WHICH INCLUDES COSTS FOR BID PACKAGE PREPARATION, CONTRACT MANAGEHENT \& ADHINISTRATION AND PROJECT MANGEMENT \& PLANNING SUPPORT.

C. INDIRECT COSTS

FIXED PRICE CONTRACTOR OVERHEAD, PROFIT, BONO AND IHSURANCE COSTS HAVE BEEN APPLIED ARE THE FOLLUOING PERCENTAGES:

LABOR $=25.0 \%$, EQUIMENT USE $=25.0 \%$, HATERIAL $=25.0 \%$, SUBCONTRACT $=10.0 \%$, AND EQUTPMEHT = OX, AND ARE REFLECTED IX THE "OH\&P/B\&I" COLUMN OF THE ESTIMATE DETAIL REPORT.

D. RATES

(8) FLUOR DANIEL NORTHHEST LABOR BATES ARE BASED UPON THE FLUOR DAINEL FEDERAL OPERATIONS (FEDFO) DISCLOSURE STATEMENT ANO APPROVED PROVISIONAL BILLING RATES. FOR ESTIMATING PURPOSES, AVEPAGE RAIES BY OPERATIONS CODE HAVE BEEN DEVELOPED BASED UPON RECENT COST HISTORY.

4. ESCALATION

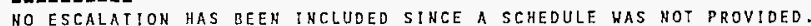


FLUOR DANIEL NORTHUEST, INC.

OUKE ENGINEERING \& SERVICES

FILE NO. YAB2SAD

5. CONTINGENCY

A CONTIHGENCY AMALYS:S HAS BEEN PERFORMEO AND 15 DOCUMENTEO IN FONHROG REPORT OF THIS ESTIMATE.

6. REMARKS

MAJOR ASSUMPTIONS HHICH HAVE BEEN MADE IN THE PREPARATION OF IHIS ESTIMATE ARE AS FOLLOHS:

A. SITE ALLOCATIONS ARE NOT INCLUDED IN THIS ESTIMATE AT THE CUSTOMERS (OESH) REQUEST.

B. OTHER PROJECT COSTS (OPC) ARE NOT INCLUDED IN THIS ESTIMATE AT THE CUSTOMERS (DESH) REQUEST.

C. THE ESTIMATE IS BASED ON THE OESIGN AND INSTALLATION K-BASINS SLUDGE PRE-TREATMENT.

C. THE ESTHATE ASSUSES ENGINEERING DESIGN, ANO E\&I OURIHG CONSTRUCTION PERFORMED BY FONW.

E. CONSTRUCT

F. NO HAZARDOUS HASTE REMOVAL OR DISPOSAL COSTS ARE IMCLUDED.

G. THE ESTIMATE ASSUMES NO RADIATION WORK WILL BE ENCOUNTERED.
PACE 4 OF 8

$08: 35: 24$

BY DEA, RH, LHR 
FLUOR DANIEL NORTHHEST, INC, DUKE ENGINEERING \& SERVICES JOB NO. E33936/F3YC4F

ILE NO. YABZSAD

\section{$\cos T$}

$\operatorname{COST}$
$\operatorname{COOE} /$ WBS

DESCRIPTION

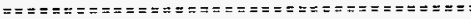

OOO ENGINEERING

111100 DEFINITIVE DESIGN-CAT 1-ONSITE E/C 121000 ENGINEERING/INSPECTION-ONSITE E/C

TOTAL DOO. ENGINEERING

700 SPECIAL EQUIPJPROCESS SYSTEMS

220000 PROCUREMENT-O/C
320000 CONSTRUCTION-FIXED PRICE

TOTAL 700 SPECIAL EQUIP/PROCESS SYSTEM

2725413

8375732

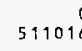

3236429

511016

8886748

0.00

0.00

0.00
0.00

0.00

0

0

408000

1360000

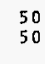

50

476000
204000

680000

612000

2040000

$1977611 \quad 7627930$ $1618216 \quad 4854645$

$3595827 \quad 12482575$

PROJECT TOTAL.

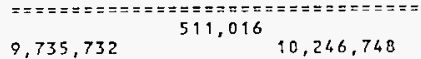

0.00

$==$

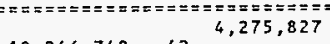

$9,735,732$

$10,246,748$

$14,522,575$ 
FLUOR DANIEL NORTHWEST, INC. DUKE ENGINEER:NG \& SERVICES

JOB NO. E33936/F3YC4

FILE NO. YABZSAD T

CSI DESCRIPTION

= = = =

ENGINEERING

OO TECHNICAL SERVICES

01 GEHERAL REQUIRMENTS

TOIAL ENGIHEERIYG

construction

\begin{tabular}{|c|c|}
\hline 03 & CONCRETE \\
\hline 05 & METALS \\
\hline 09 & FINISHES \\
\hline 11 & EQUIPMENT \\
\hline 15 & MECHANICAL \\
\hline 16 & ELECTRICAL \\
\hline
\end{tabular}

TOTAL CONSTRUCTION

PROJECT TOTAL
* * IEST - INTERACTIVE ESTIMATING *

SLUDGE PRE-TREATMENT, K- BASINS; OPT ION 4

FDNUROS - ESTIMATE SUMMARY BY CSI DIVISION
PAGE 6 OF 8

DATE $06 / 11 / 97 \quad 11: 49: 15$

BY DEA, RW, LYR

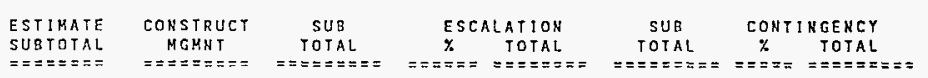
$=======$ $=\bar{x}===-=5==$ $====z$ $===$

TOTAL DOLLARS

$\begin{array}{rrrrrrrrr}952000 & 0 & 952000 & 0.00 & 0 & 952000 & 50 & 476000 & 1428000 \\ 408000 & 0 & 408000 & 0.00 & 0 & 408000 & 50 & 204000 & 612000 \\ & 0 & & & 0 & & & 680,000 & \\ 360,000 & & 1,360,000 & 0.00 & & 1,360,000 & 50 & & 2,040,000\end{array}$

\begin{tabular}{|c|c|c|c|c|c|c|c|c|}
\hline $\begin{array}{r}20668 \\
3117891 \\
108030 \\
2443652 \\
824963 \\
1860528\end{array}$ & $\begin{array}{r}3875 \\
161555 \\
20256 \\
0 \\
69631 \\
255699\end{array}$ & $\begin{array}{r}24543 \\
3279446 \\
128286 \\
2443652 \\
894594 \\
2116227\end{array}$ & $\begin{array}{l}0.00 \\
0.00 \\
0.00 \\
0.00 \\
0.00 \\
0.00\end{array}$ & $\begin{array}{l}0 \\
0 \\
0 \\
0 \\
0 \\
0\end{array}$ & $\begin{array}{r}24543 \\
3279446 \\
128286 \\
2443652 \\
894594 \\
2116227\end{array}$ & $\begin{array}{l}50 \\
40 \\
50 \\
35 \\
42 \\
46\end{array}$ & $\begin{array}{r}12272 \\
1301283 \\
64143 \\
855278 \\
379257 \\
983594\end{array}$ & $\begin{array}{r}36815 \\
4580729 \\
192429 \\
3298930 \\
1273851 \\
3099821\end{array}$ \\
\hline 75.732 & 511,016 & $8,886,748$ & 0.00 & 0 & $8,886,748$ & 40 & 95,827 & $12,482,575$ \\
\hline
\end{tabular}

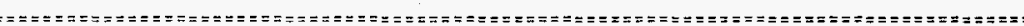

511,096

$9.735,732$

$10,246,748$

0.00

0

$=======$
$4,275,827$

$14,522,575$ 
FLUOR DANIEL, NORTHWEST, INC. DUKE EHGINEERIMG \& SERVICES JOB NO. EJ3OJ6/FJYCLF

EILE NO YABZSAO
* iest - interactive estimailng *

SLUDGE PRE-TREATMENT, X- BASIHS: OPTIOA 4

FONHROG - CONTTUGEUCY AUALYSIS BASIS SHEET
PAGE 7 OF 8

DATE 06/05/97 08:35:24

BY DEA, RU, L 48

Revised $3 / 25 / 97 \quad 14: 14$

1. DEFIHITIOH OF CONTINGENCY AS PROVIDEO BY DOE

"CONTINGENCY COVERS COSTS THAT HAY RESULI FROM INCOMPLETE DESIGN, UNFORESEEN ARO UNPREDICTABLE CONOITIONS, OR UNCERTAINTIES WITIN THE DEFIMED PROJECT SCOPE. TIIE AROUNT OF CONTINGENCY HILL OEPEND ON THE STATUS OF DESIGN, PROCUREMENT. AND CONSTRUCTION: AHO TRE COHPLEXITY AND UNCERTAINTIES OF THE COMPONENT PARTS OF THE PROJECT. COHTINGENCY IS NOT TO BE USED TO AVOID MAXING AN ACCURATE ASSESSMENT OF EXPECTED COST" (OFFICE OF HASTE MANAGEMENT (EM-3O) COST AHD SCHEDULE GUIDE).

2. CONTINGENCY ALLOHANCE GUIOELINES

THE DOE GUIDELINE CONTIHGENCY ALLOUAHCE FOR A ROUGH ORDER OF MAGNITUDE ESTIMATE.

PLANYING ESITMAT. EXPERIMENTALISPECIAL CONDITIONS = UP TO $50 \%$

2. MEIUODOLOGY

$== \pm=\equiv==\Sigma$

CONTINGENCY IS EVALUATED AT THE LOWEST WORK BREAKOOHN STRUCTURE (HBS) LEVEL WITHIN IHE COST ESTIMATE DETAILS. IT IS SUMMARIZED AT UPPER WBS LEVELS AND REPORTED ON THE SUMMARY REPORTS

3. ANALYSIS

AN ASSESSHENT OF DESISN MATUR:TY, HORX COMPLEXITY AMD PROJECT UNCERTAINTIES HAS BEEN PERFORMED.

AR EXPLAINATION OF THIS ASSESSMENT AND CONTIGENCY RATES WHICH HAVE BEEN ADDED TO THE COST OF WORK ARE AS FOLLOUS:

WOS IT DEFINITIVE DESIGH, CONTINGENCY OF SO\% KAS BEEN APPLIED.

HBS 12 ENGINEERIHG INSPECTION A CONTIUEEYCY OF $50 \%$ HAS BEEN APPLIED.

WBS 2 ENGINEERING/INSPECTION, A CONTINGENCY OF SO\% HAP BEEN

HOS 32 FIXEO PRICE CONTRACTOR, CONTIHGENCY OF $50 \%$ HAS BEE A APPLIED. 


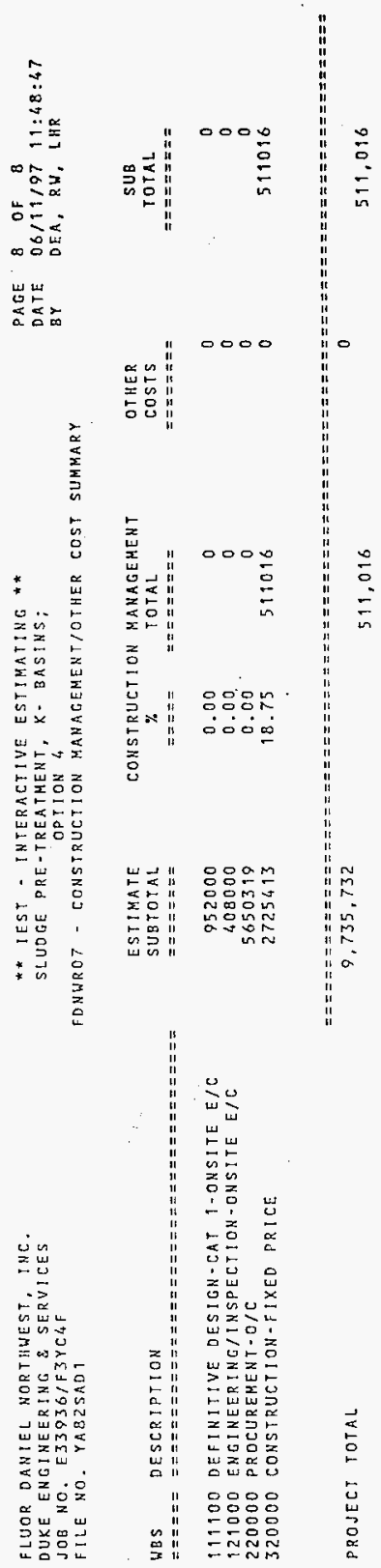


HNF-SD-SNF-PCR-002, Rev. 0

APPENDIX B

Equipment List 
Appendix B: Equipment List

EQUIPMENT LIST

K BASIN SLUDGE REMOVAL PRETREATMENT PROJECT

WORK ORDER E33937

June 5, 1997

\begin{tabular}{|c|c|c|c|}
\hline$O T^{\prime} Y$ & DESCRIPTION & $\begin{array}{l}\text { EQUIPMENT } \\
\text { NO. }\end{array}$ & SPECIFICATION \\
\hline 1 & DISSOLVER & $T-1$ & $\begin{array}{l}1,000 \text { GALLON, 5'-0" D X 7'-6" H, WITH AGITATOR AND } \\
\text { COOLING/HEATING COIL, 304L STAINLESS, } 15 \text { PSIG AT } \\
\text { 200F. }\end{array}$ \\
\hline 1 & $\begin{array}{l}\text { pH ADJUSTMENT } \\
\text { TANK }\end{array}$ & $T-2$ & $\begin{array}{l}800 \text { gallon, } 4^{\prime}-6^{\prime \prime} \mathrm{D} \times 8^{\prime}-6 " \mathrm{H}, \text { WITH AGITATOR, } 304 \mathrm{~L} \\
\text { STAINLESS, } 15 \text { PSIG AT 200F. }\end{array}$ \\
\hline 1 & REWORK TANK & $T-3$ & $\begin{array}{l}500 \text { GALLON, } 4^{\prime}-0 " D \times 7^{\prime}-6 " H, \text { WITH AGITATOR, } 304 L \\
\text { STAINLESS, } 15 \text { PSIG AT } 200 \mathrm{~F} \text {. }\end{array}$ \\
\hline 1 & $\begin{array}{l}50 \% \text { NITRIC ACID } \\
\text { RECOVERY TANK }\end{array}$ & $\mathrm{T}-4$ & $\begin{array}{l}400 \text { GALLON, } 2^{\prime}-6 " D \times 5^{\prime}-0 " H, 304 L \text { STAINLESS, } 15 \text { PSIG } \\
\text { AT } 200 \mathrm{~F} .\end{array}$ \\
\hline
\end{tabular}




\begin{tabular}{|c|c|c|c|}
\hline 1 & $\begin{array}{l}\text { SODIUM } \\
\text { HYDROXIDE } \\
\text { SOLUTION TANK }\end{array}$ & $T-5$ & $\begin{array}{l}\text { 2,500 GALLON, 6'-6"D X } 13 \text { '-0"H, 304L STAINLESS, } 15 \\
\text { PSIG AT } 120 F . \text { OUTDOOR TANK. MAINTAIN TANK } \\
\text { SOLUTION AT } 60 \text { F OR HIGHER WITH HEAT TRACING. } \\
\text { CHROMALOX SL-48-24-48OV-200W, } 480 \mathrm{~V} 3 \text { PH } 200 \mathrm{~W} . \\
\text { SRL-10-2CT SELF REGULATING HEAT TRACE 1OW/FT AT } \\
\text { 50-F } 240 \mathrm{~V} \text {. }\end{array}$ \\
\hline 1 & $\begin{array}{l}\text { HOT WATER TANK } \\
\text { WITH HEATER }\end{array}$ & $T-6$ & $\begin{array}{l}250 \text { GALLOON, 3'-O" D X 6'-O" H, WITH } 1 \text { " INSULATION } \\
\text { AND IMMERSION HEATER INSIDE THE TANK, 304L } \\
\text { STAINLESS, } 15 \text { PSIG AT 2OOF. IMMERSION HEATER } \\
\text { CHROMALOX, COPPER ELEMENTS, TM-36125E4XX } 480 \mathrm{~V} \\
\text { 3PH 125KW. } 4432-36111 \text { CONTACTOR PANEL, NEMA } 12 \\
\text { ENCLOSURE } 2104 \text { TEM CONTROLLER } 3101 \text { OVERTEMP } \\
\text { CONTROLLER. } 1225 \text { AMP CONTACTOR. }\end{array}$ \\
\hline 1 & $\begin{array}{l}\text { NITRIC ACID } \\
\text { STORAGE TANK }\end{array}$ & $T-7$ & $\begin{array}{l}\text { 5,000 GALLON, 8'-6"D X } 16^{\prime}-6 " \mathrm{H} \text {, FIBERGLASS, } \\
\text { ATMOSPHERIC, } 120 \mathrm{~F} \text { WITH } 1 \text { " INSULATION. }\end{array}$ \\
\hline 4 & $\begin{array}{l}\text { DILUTE NITRIC ACID } \\
\text { TANKS }\end{array}$ & $T-8$ & $\begin{array}{l}100 \text { GALLON, } 2^{\prime}-6 " \mathrm{H} \times 5^{\prime}-0^{\prime \prime} \mathrm{H}, 304 \text { L STAINLESS, } 15 \\
\text { PSIG AT 200F. }\end{array}$ \\
\hline 1 & $\begin{array}{l}\text { HYDROGEN } \\
\text { PEROXIDE STORAGE } \\
\text { TANK }\end{array}$ & T-9 & $\begin{array}{l}2,500 \text { GALLON. 6'-6"D X } 13^{\prime}-0^{\prime \prime H} .304 \text { L STAINLESS, } 15 \\
\text { PSIG AT } 120 \mathrm{~F} \text { WITH } 1 " \text { INSULATION. }\end{array}$ \\
\hline 1 & HEXANE TANK & $T-10$ & $\begin{array}{l}600 \text { GALLON, 4'-O" X 8'-O" H, 304L STAINLESS STEEL, } 15 \\
\text { PSIG AT } 120 \mathrm{~F} \text { WITH } 1 \text { " INSULATION. }\end{array}$ \\
\hline
\end{tabular}




\begin{tabular}{|c|c|c|c|}
\hline$Q T^{\prime} Y$ & DESCRIPTION & $\begin{array}{l}\text { EOUIPMENT } \\
\text { NO. }\end{array}$ & SPECIFICATION \\
\hline 1 & $\begin{array}{l}\text { WATER SOLUTION } \\
\text { TANK }\end{array}$ & $\mathrm{T}-11$ & $\begin{array}{l}1000 \text { GALLON, } 1,000 \text { GALLON, 5'-0" D X 7'-6" H, 304L } \\
\text { STAINLESS, } 15 \text { PSIG AT } 120 \mathrm{~F} .\end{array}$ \\
\hline 1 & $\begin{array}{l}\text { WATER CATCH } \\
\text { TANK }\end{array}$ & $\mathrm{T}-12$ & 20 GALLON, $2^{\prime}-0 " D \times 11^{\prime}-0 " \mathrm{H}, 304$ STAINLESS STEEL \\
\hline 1 & $\begin{array}{l}\text { DISSOLVER TOWER } \\
\text { CONDENSATE TANK }\end{array}$ & $\mathrm{T}-13$ & $\begin{array}{l}100 \text { GALLON, 2'-6" H X 5'-0" H, 304L STAINLESS, } 15 \\
\text { PSIG AT 2OOF. }\end{array}$ \\
\hline 1 & $\begin{array}{l}\text { CENTRIFUGE } \\
\text { (UPSTREAM OF } \\
\text { DISSOLVER) }\end{array}$ & C- 1 & $\begin{array}{l}6 \text { GALLON ROTOR CAPACITY, BOTTOM GRAVITY CAKE } \\
\text { DISCHARGE, WITH OVERALL DIMENSIONS OF } 24 " \text { " } 52 \text { " } \\
\times \text { 70" TALL, } 460 \vee 3 \text { PHASE } 5 \text { HP MOTOR, PLC } \\
\text { CONTROLLED, BAZELL TECHNOLOGIES } \\
\text { 'MICROSEPERATOR', MODEL TSK } 150 A 2, \text { APPROXIMATE } \\
\text { COST \$62K. }\end{array}$ \\
\hline 1 & $\begin{array}{l}\text { CENTRIFUGE } \\
\text { (UPSTREAM OF PH } \\
\text { ADJ. TANK) }\end{array}$ & $C-2$ & $\begin{array}{l}6 \text { GALLON ROTOR CAPACITY, BOTTOM GRAVITY CAKE } \\
\text { DISCHARGE, WITH OVERALL. DIMENSIONS OF } 24 " \times 52 " \\
\times \text { 70" TALL, } 460 \vee 3 \text { PHASE } 5 \text { HP MOTOR, PLC } \\
\text { CONTROLLED, BAZELL TECHNOLOGIES } \\
\text { 'MICROSEPERATOR', MODEL TSK 15OA2, APPROXIMATE } \\
\text { COST \$62K. }\end{array}$ \\
\hline
\end{tabular}




\begin{tabular}{|c|c|c|c|}
\hline$O T^{\prime} Y$ & DESCRIPTION & $\begin{array}{c}\text { EQUIPMENT } \\
\text { NO. }\end{array}$ & SPECIFICATION \\
\hline 1 & ACID ABSORBERS & $A B-1$ & $\begin{array}{l}3 \text { FT DIA X } 14 \text { FT, } 3 \text { COUNTER CURRENT STAGES, ALL } \\
316 \text { STAINLESS STEEL, TWO ABSORBERS IN SERIES, } \\
\text { SUPPLIED BY AEA TECHNOLOGY, TOTAL COST APPROX } \\
\$ 800 .\end{array}$ \\
\hline 1 & $\begin{array}{l}\text { HEATER(UPSTREAM } \\
\text { OF SILVER } \\
\text { REACTOR) }\end{array}$ & $H X-2$ & $\begin{array}{l}\text { HIGH TEMPERATURE AIR DUCT HEATER, TWO IN SERIES, } \\
30 \mathrm{KW} \text { EACH, APPROX } 15^{\prime \prime} \times 11^{\prime \prime} \times 28 \text { " LONG, } \\
\text { CHROMALOX MODEL ADH-030. }\end{array}$ \\
\hline 1 & $\begin{array}{l}\text { NITRIC ACID } \\
\text { CONDENSER } \\
\text { (DOWNSTREAM OF } \\
\text { ABSORBER) }\end{array}$ & $H X-3$ & $\begin{array}{l}\text { SHELL } T \text { UBE HEAT EXCHANGER, ASSUMED SIZE: } 4 \text { " DIA } \\
\text { FLANGE CONN, APPROX } 1 \text { FT X } 1 \text { FT } 4 \text { IN X } 11 \text { FT LONG, } \\
\text { BALTIMORE AIRCOIL HIGH-K HEAT EXCHANGER, MODEL. } \\
\text { HK-6-9-1-1. }\end{array}$ \\
\hline
\end{tabular}




\begin{tabular}{|c|c|c|c|}
\hline QT'Y & DESCRIPTION & $\begin{array}{l}\text { EQUIPMENT } \\
\text { NO. }\end{array}$ & SPECIFICATION \\
\hline 1 & $\begin{array}{l}\text { SLURRY FILTER } \\
\text { (DOWNSTREAM OF } \\
\text { DISSOLVER) }\end{array}$ & SF-1 & $\begin{array}{l}\text { TO SEPARATE PARTICLES LARGER THAN } 50 \mu \mathrm{M} \text { SIZE TO } \\
\text { CENTRIFUGE AND SLURRY DISCHARGES TO } \mathrm{pH} \\
\text { ADJUSTMENT TANK. }\end{array}$ \\
\hline 1 & $\begin{array}{l}\text { NITRIC ACID } \\
\text { FRACTIONATOR } \\
\text { INCLUDING } \\
\text { REBOILER }\end{array}$ & FR-1 & $\begin{array}{l}2 \text { FT DIA } X 10 \mathrm{FT}, \text { WITH } 4 \text { TO } 5 \text { THEORETICAL STAGES, } \\
\text { ALL } 316 \text { STAINLESS STEEL, SUPPLIED BY AEA } \\
\text { TECHNOLOGY, APPROX } \$ 500 \mathrm{~K} .\end{array}$ \\
\hline 1 & $\begin{array}{l}\text { SLUDGE PUMP } \\
\text { (EXISTING) }\end{array}$ & N/A & $\begin{array}{l}50 \text { GPM, } 30 \text { VOL \% SLUDGE FROM LOADOUT BIN. AIR } \\
\text { OPERATED DIAPHRAGM }\end{array}$ \\
\hline 1 & $\begin{array}{l}\text { WATER SOLUTION } \\
\text { TANK PUMP }\end{array}$ & $\mathrm{P}-1$ & 50 GPM, 30-FT HEAD, SIMILAR TO WATER \\
\hline 1 & $\begin{array}{l}\text { HEXANE RECIRC } \\
\text { PUMP }\end{array}$ & $P-2$ & $\begin{array}{l}5 \text { GPM, 30-FT TDH, } 50 \% \text { HEXANE, NO SOLID. AIR } \\
\text { OPERATED DIAPHRAGM PUMPS }\end{array}$ \\
\hline 2 & $\begin{array}{l}\text { DISSOLVER FLUID } \\
\text { TRANSFER PUMP }\end{array}$ & $P-3$ & $\begin{array}{l}10 \text { GPM, 30-FT TDH, FLUID WITH LESS THAN } 50 \% \text { NITRIC } \\
\text { ACID, LESS THAN } 1 / 4 " \text { SIZE SOLID, SLURRY }\end{array}$ \\
\hline 2 & $\begin{array}{l}\text { PH ADJUST. TANK } \\
\text { TRANSFER PUMP }\end{array}$ & $P-4$ & 20 GPM, 30-FT TDH. SLIGHTLY CAUSTIC, SLURRY \\
\hline 2 & $\begin{array}{l}\text { REWORK TANK } \\
\text { TRANSFER PUMP }\end{array}$ & $P-5$ & 20 GPM, 30-FT TDH, SLIGHTLY CAUSTIC, SLURRY \\
\hline 2 & $\begin{array}{l}\text { NITRIC ACID FEED } \\
\text { PUMP }\end{array}$ & P-6 & $20 \mathrm{GPH}$, CENTRIFUGAL PUMP \\
\hline
\end{tabular}




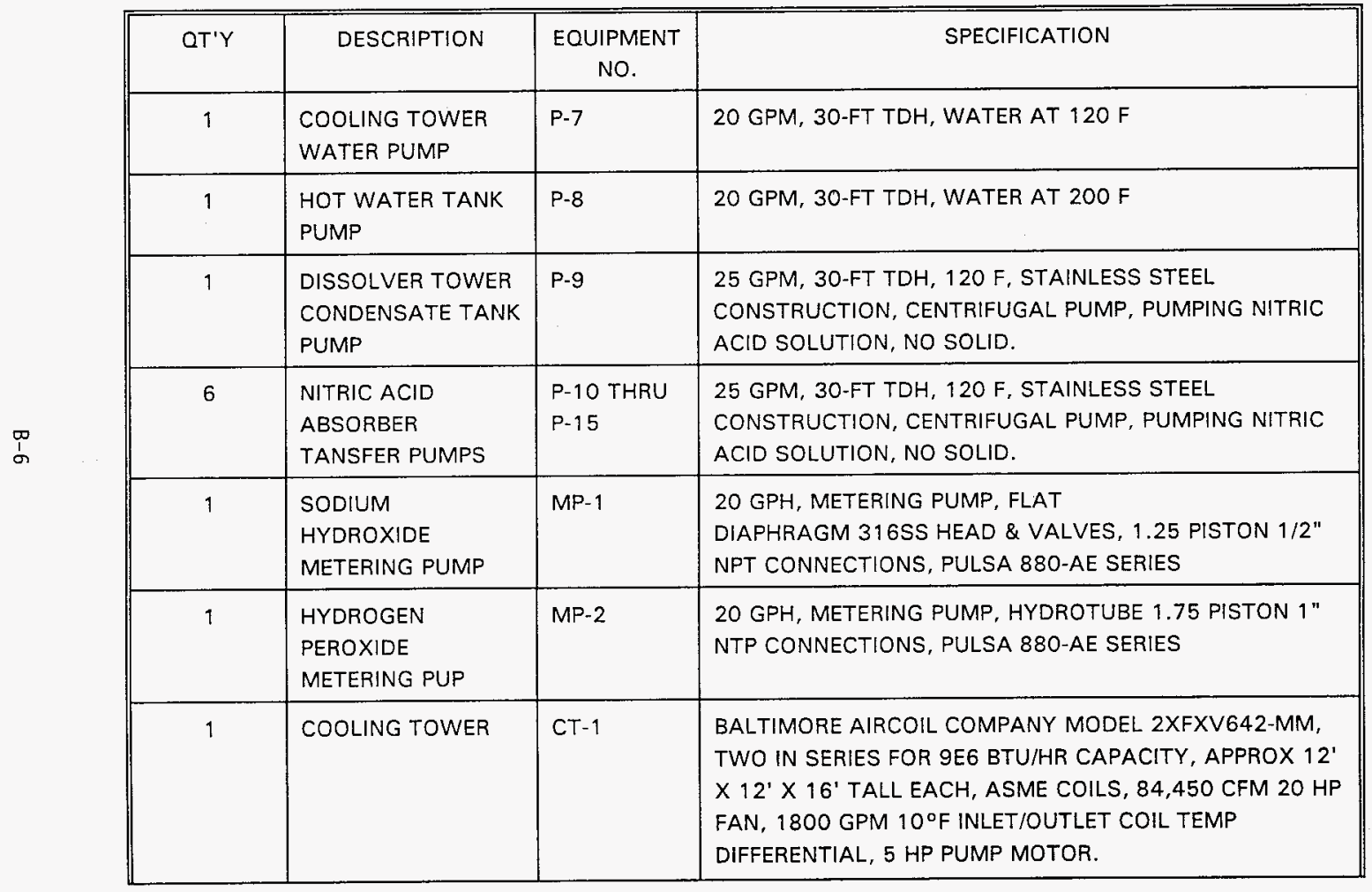




\begin{tabular}{|c|c|c|c|}
\hline OT'Y & DESCRIPTION & $\begin{array}{l}\text { EOUIPMENT } \\
\text { NO. }\end{array}$ & SPECIFICATION \\
\hline 1 & SILVER REACTOR & $R-1$ & $\begin{array}{l}3 \text { FT OD X } 9 \text { FT TALL SILVER REACTOR VESSEL, PACKED } \\
\text { BED WITH SILVER NITRATE BERL SADDLES, SIZED BASED } \\
\text { ON PUREX SILVER REACTOR AND IT'S RELATIVE OFF-GAS } \\
\text { THRU PUT. }\end{array}$ \\
\hline 2 & HEAT PUMPS & $\mathrm{HP}-1, \mathrm{HP}-2$ & $\begin{array}{l}\text { AIR CONDITIONING HEAT PUMP UNITS, 3-TON, DX } \\
\text { SYSTEM, AIR COOLED/HEATED TO SERVE AIR HANDLING } \\
\text { UNITS. }\end{array}$ \\
\hline 1 & AIR CONDITIONER & $A C-2$ & $\begin{array}{l}\text { AIR CONDITIONING UNIT, SELF-CONTAINED, WALL- } \\
\text { MOUNTED, } 1.5 \text { TON, DX SYSTEM, WITH FILTER AND } \\
\text { ELECTRIC HEAT. }\end{array}$ \\
\hline 1 & DUCT HEATER & $\mathrm{DH}-1$ & $\begin{array}{l}\text { ELECTRIC DUCT HEATER, PRE-HEATER FOR HEPA FILTER. } \\
5 \mathrm{KW}, 480 \mathrm{~V} / 3 \mathrm{PH} .\end{array}$ \\
\hline 2 & $\begin{array}{l}\text { INTAKE HEPA } \\
\text { FILTERS }\end{array}$ & $F-1, F-2$ & DISPOSABLE HEPA FILTER, 500 CFM MAX. $12^{\prime \prime} \times 12 "$. \\
\hline
\end{tabular}




\begin{tabular}{|c|c|c|c|}
\hline QT'Y & DESCRIPTION & $\begin{array}{l}\text { EQUIPMENT } \\
\text { NO. }\end{array}$ & SPECIFICATION \\
\hline 1 & $\begin{array}{l}\text { PRIMARY HEPA } \\
\text { FILTER }\end{array}$ & $\mathrm{F}-3$ & DISPOSABLE HEPA FILTER, 1,000 CFM MAX. $12 " \times$ " 24". \\
\hline 1 & OFFICE PRE-FILTER & $\mathrm{F}-4$ & $\begin{array}{l}\text { DISPOSABLE 4" PLEATED, } 500 \text { CFM, 12" X } 18 " \text {, } \\
\text { WATERPROOF MEDIA. }\end{array}$ \\
\hline 2 & $\begin{array}{l}\text { STACK EXHAUST } \\
\text { FANS }\end{array}$ & $E F-1, E F-2$ & $\begin{array}{l}\text { BLOWER TYPE CENTRIFUGAL EXHAUST FANS, } 1,000 \text { CFM } \\
\text { AT } 3 \text { IN.WG. SPARK PROOF CONSTRUCTION, } \\
\text { WEATHERPROOF HOUSING, } 1 \text { HP TEFC MOTOR. }\end{array}$ \\
\hline 1 & $\begin{array}{l}\text { WALL EXHAUST } \\
\text { FAN }\end{array}$ & $E F-3$ & $\begin{array}{l}\text { WALL-MOUNTED CENTRIFUGAL EXHAUST FAN, } 200 \text { CFM, } \\
1 / 8 \mathrm{HP} .\end{array}$ \\
\hline 1 & $\begin{array}{l}\text { STACK MONITOR } \\
\text { SYSTEM }\end{array}$ & $S M-1$ & $\begin{array}{l}\text { PRE-FABRICATED STACK MONITOR STATION TO } \\
\text { MONITOR NO }, \text { HYDROCARBONS, PARTICULATE AND } \\
\text { FLOW. INCLUDES BUILDING, GAS BOTTLE STORAGE AND } \\
\text { ANALYZING EQUIP. }\end{array}$ \\
\hline 1 & EXHAUST STACK & ST-1 & $\begin{array}{l}\text { 10" DIA X } 50 \mathrm{FT}, \text { SCH } 40 \text { FIBERGLASS STACK, } \\
\text { SECTIONAL IN 10" FLANGED SECTIONS, WITH GUY } \\
\text { WIRES. }\end{array}$ \\
\hline
\end{tabular}




\begin{tabular}{|c|l|l|l||}
\hline OT'Y & \multicolumn{1}{|c|}{ DESCRIPTION } & $\begin{array}{c}\text { EQUIPMENT } \\
\text { NO. }\end{array}$ & \multicolumn{1}{|c|}{ SPECIFICATION } \\
\hline 1 & COMPRESSOR & $\mathrm{C}-1$ & $\begin{array}{l}\text { OUINCY NORTHWEST ROTARY SCREW AIR } \\
\text { COMPRESSOR, ONW-F25, 105 SCFM 100 PSIG, 25 HP, } \\
3 / 60 / 230 / 4,60 . \text { SINGLE STAGE, HEAVY-DUTY, AIR } \\
\text { COOLED, OIL FLOODED WITH AFTER COOLER AND } \\
\text { MOTOR CONTROL }\end{array}$ \\
\hline 1 & VACUUM SYSTEM & VC-1 & $\begin{array}{l}\text { FOR RESIDUAL HEXANE REMOVAL FOR THE SOLID IN THE } \\
\text { DRUM PRIOR TO DISPOSAL }\end{array}$ \\
\hline
\end{tabular}

NOTE:

1. EQUIPMENT IS SIZED TO HANDLE 500 LBS CHARGE OF SOLIDS IN 20 VOL \% OF SLUDGE FEED. 13 CHARGES OR 6,600 LBS OF TOTAL SOLIDS IS EQUIVALENT TO 1.2 CUBIC METER OF SOLIDS 16 CUBIC METER SLUDGE OR APPROX. 1590 GALLONS). 


\title{
APPENDIX C
}

\author{
Sketches
}

ES-SNF-01, P \& IDS, K BASIN SLUDGE REMOVAL. PRETREATMENT SYSTEM

ES-SNF-02, OVERALL SIZE OF SKIDS

ES-SNF-03, SKID 1: PROCESS EQUIPMENT

ES-SNF-04, SKID 2: OFFGAS

ES-SNF-05, SKID 3: STACK \& MONITOR

ES-SNF-06, SKID 4: COOLING TOWERS

ES-SNF-07, SKID 5: CHEMICAL FEED TANKS

ES-SNF-08, SKID 6: CONTROL AND ELECTRICAL STATIONS

ES-SNF-09, ELECTRICAL ONE LINE DIAGRAM

ES-SNF-10, I \& C BLOCK DIAGRAM 


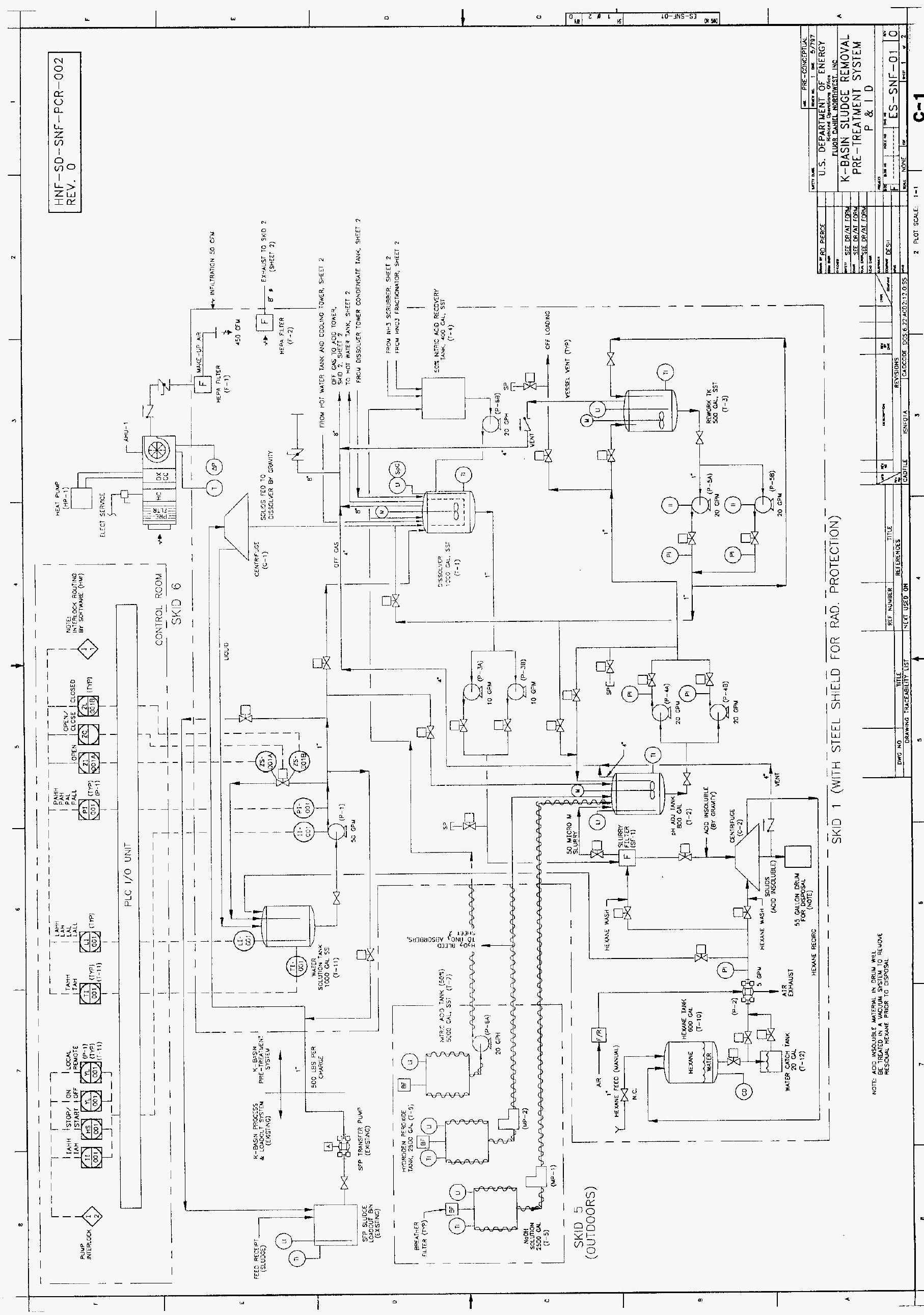



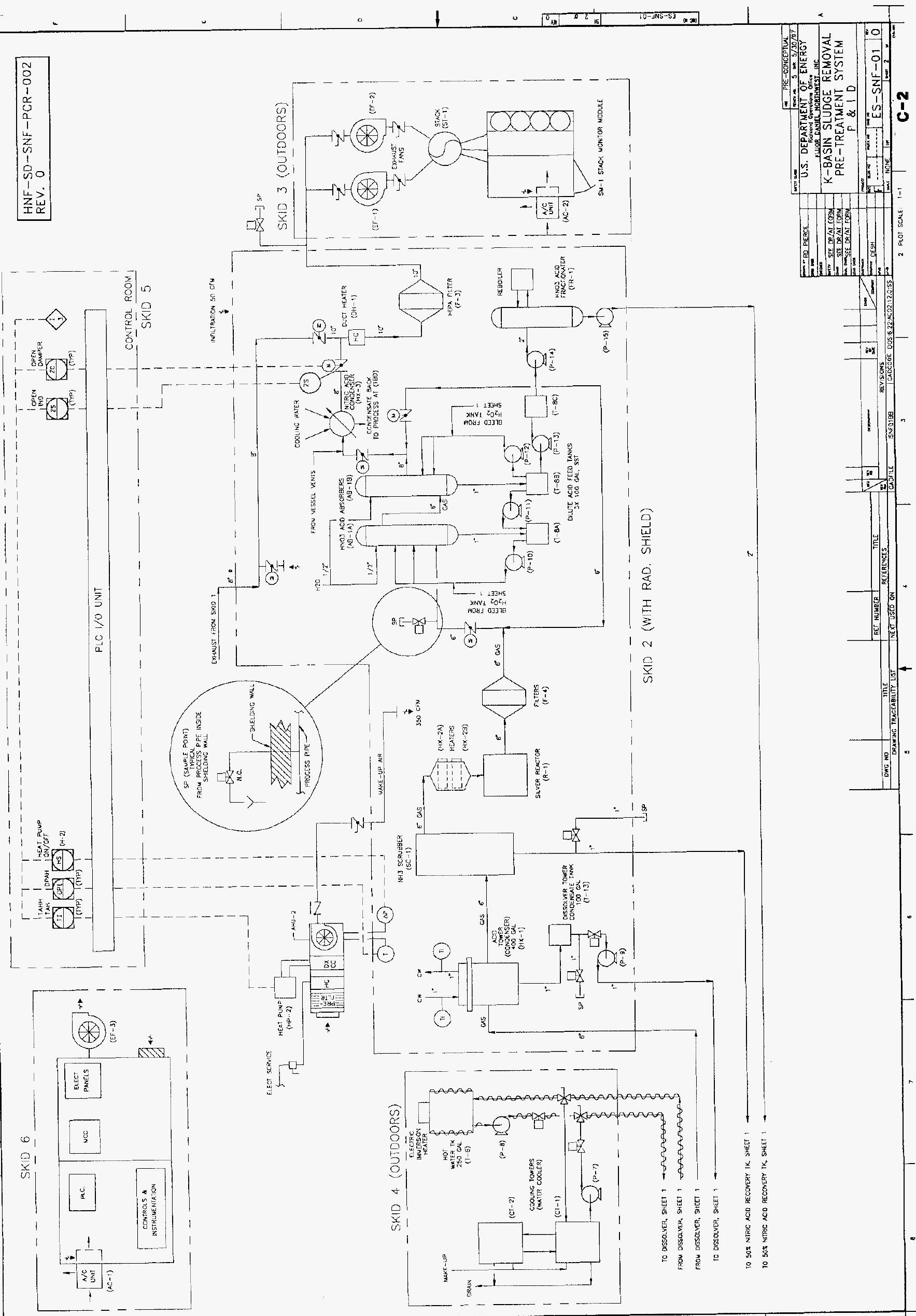


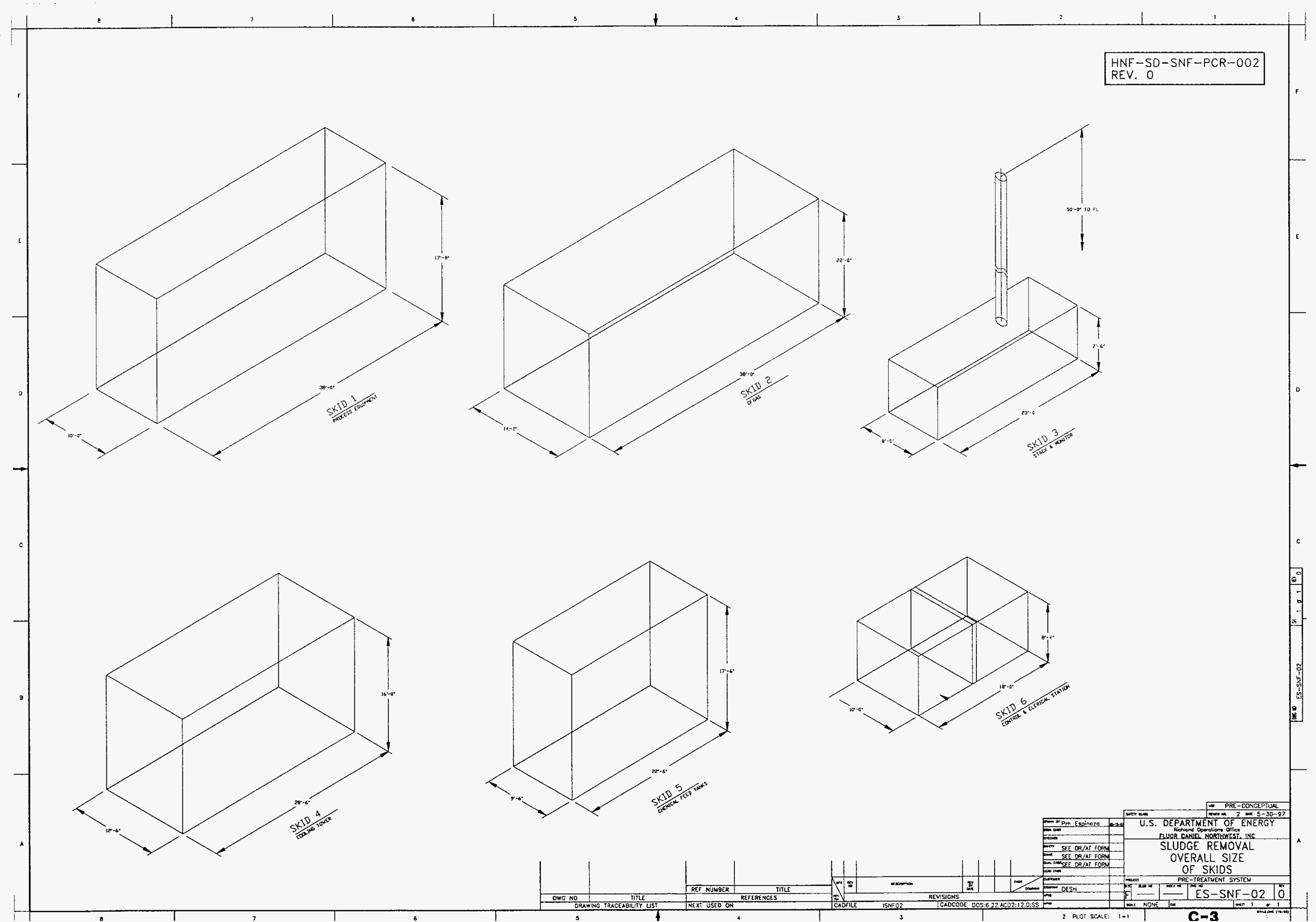




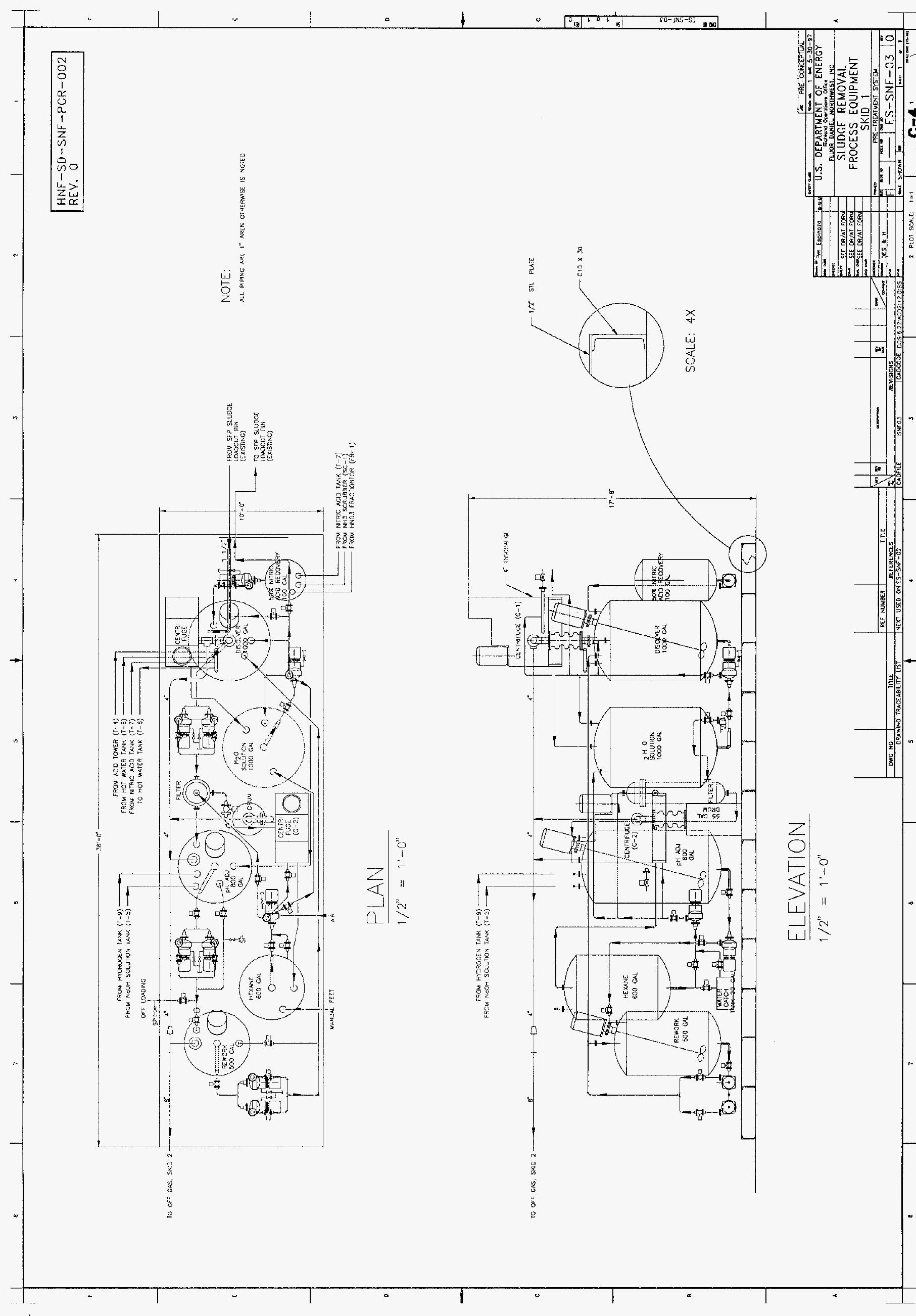




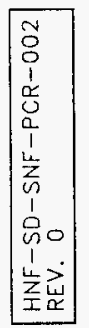

1
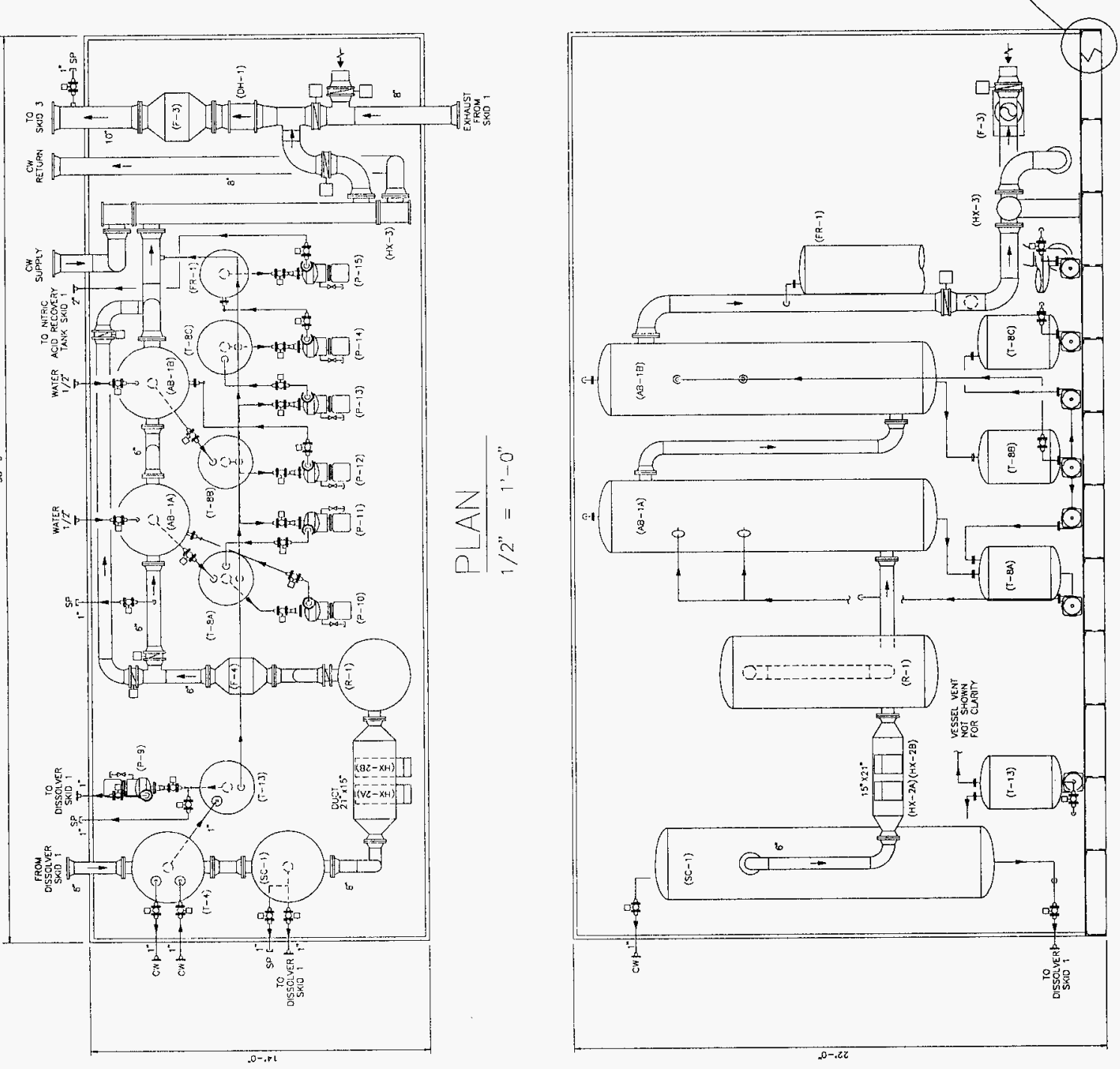

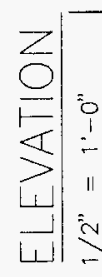

i:

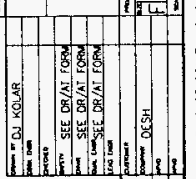

IIII)
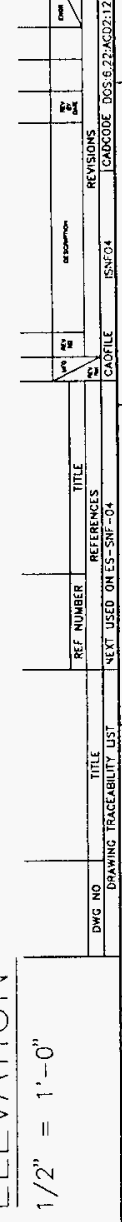


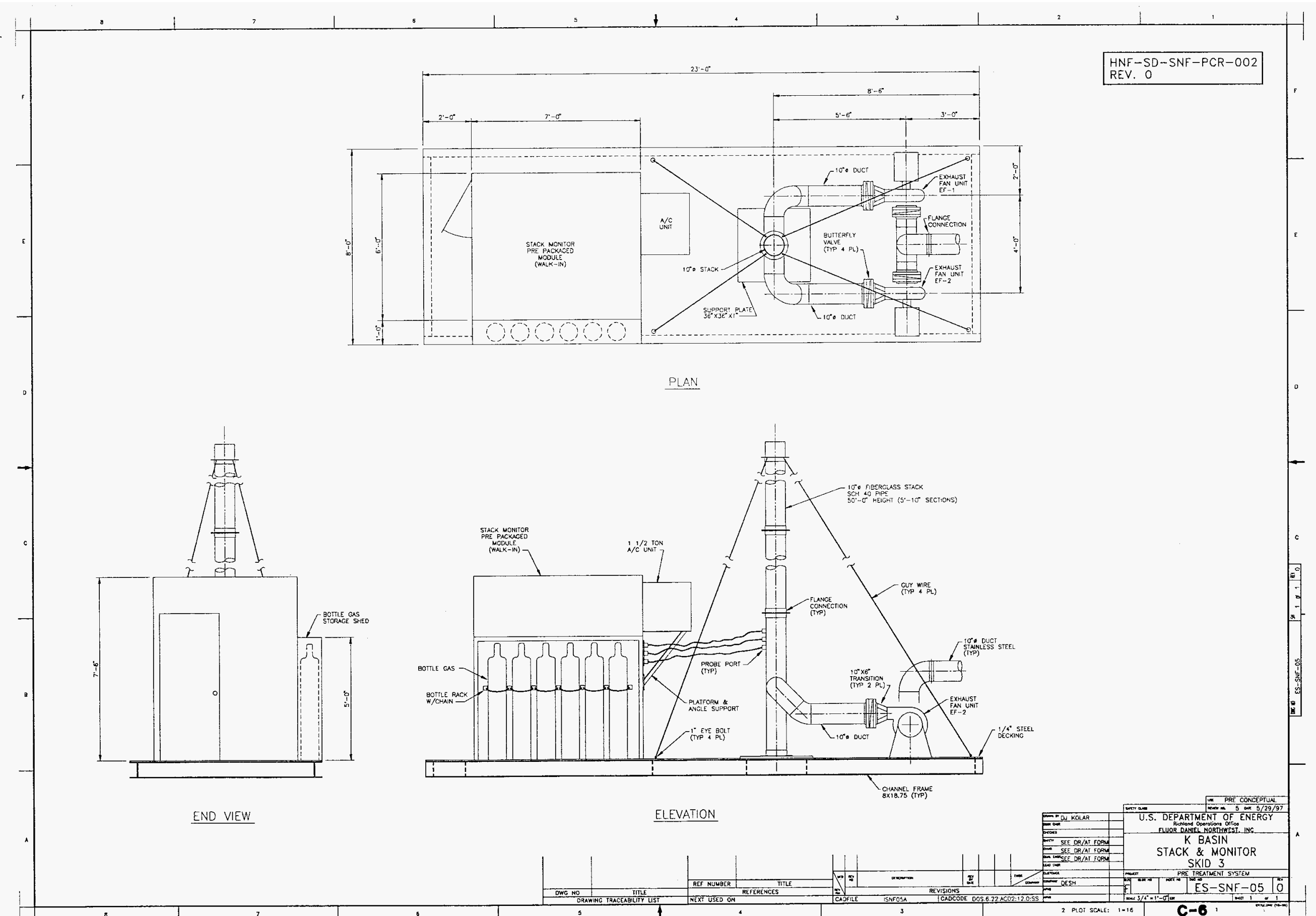




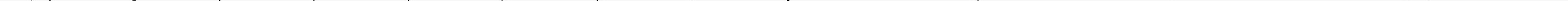




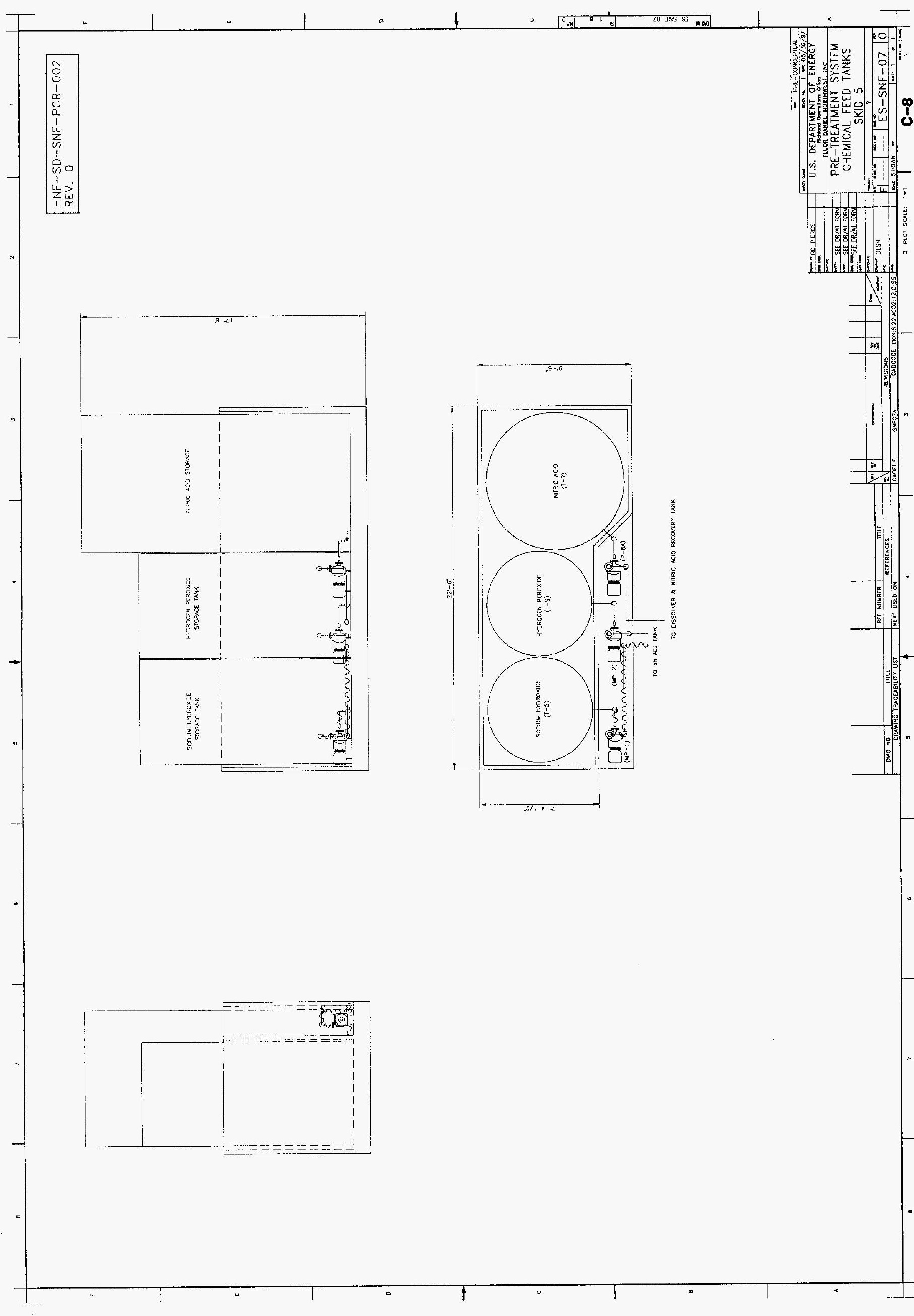




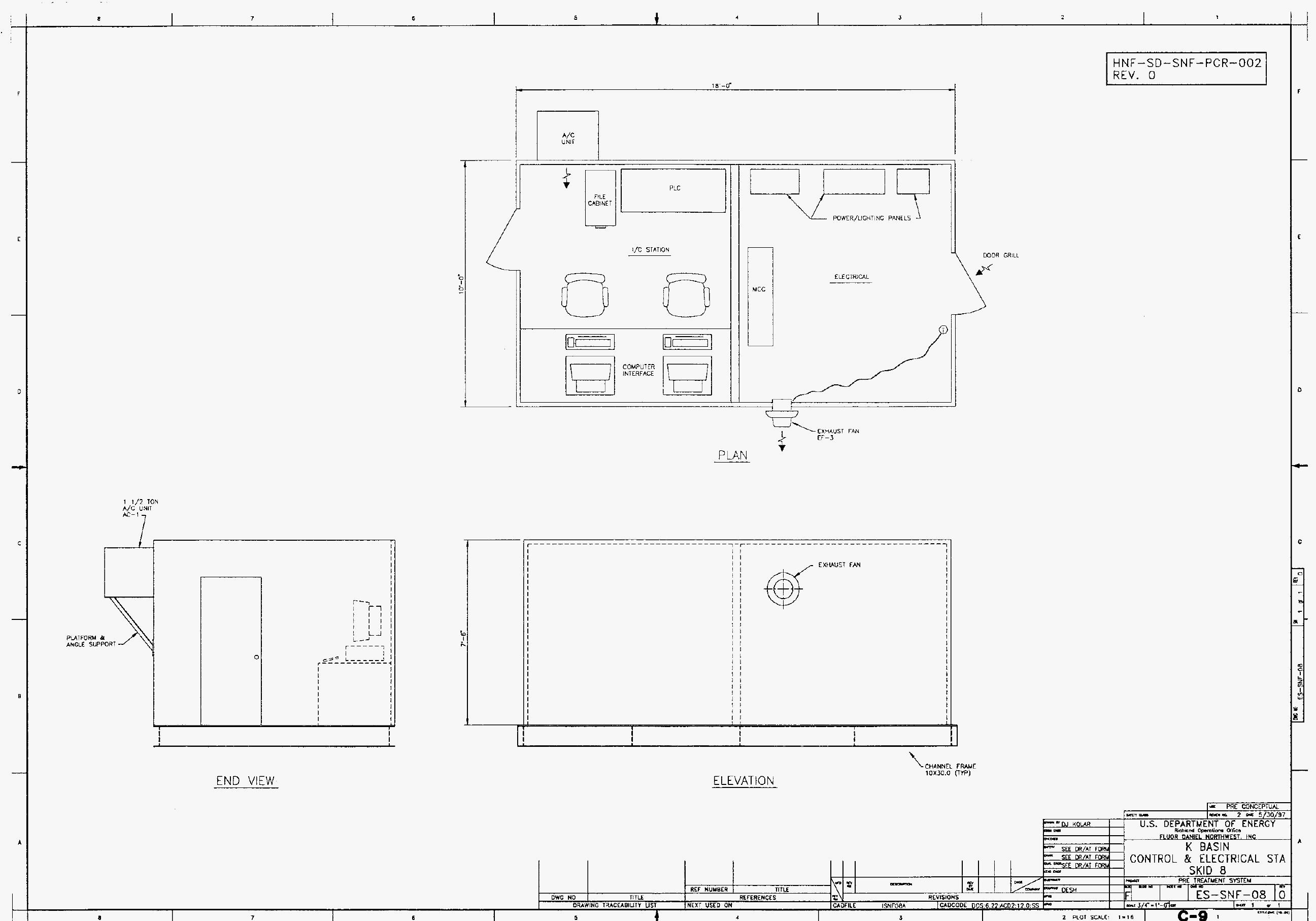




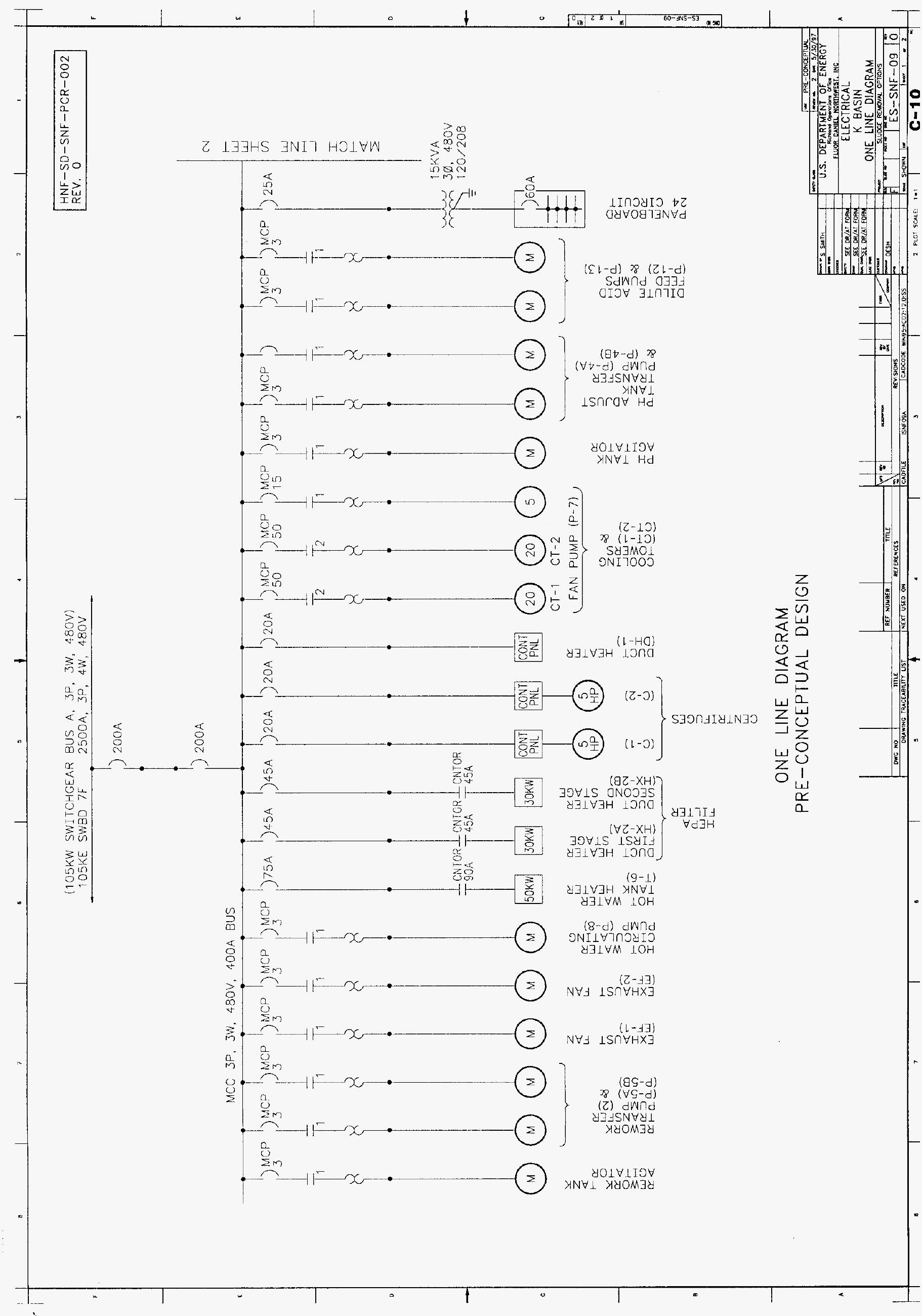




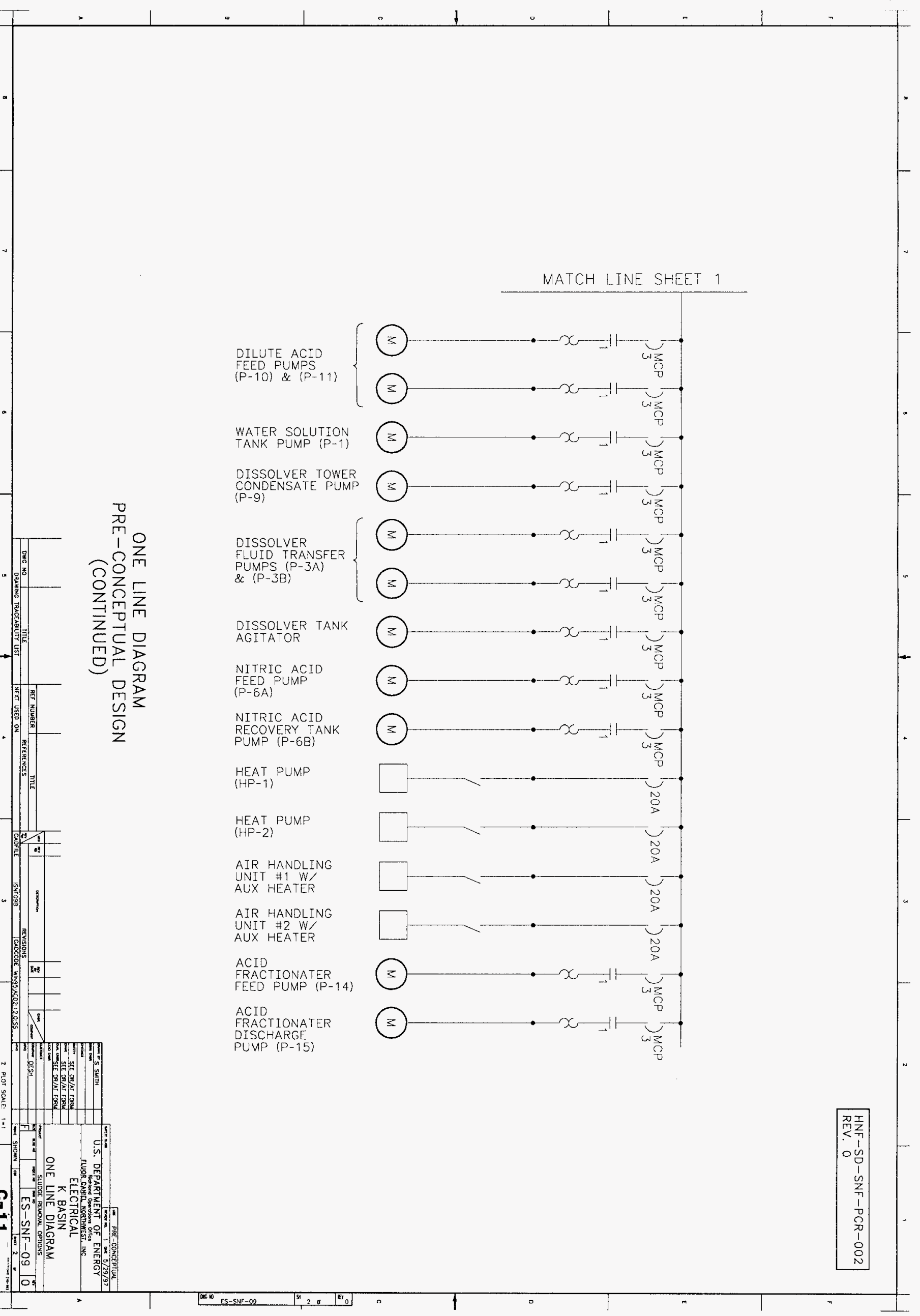




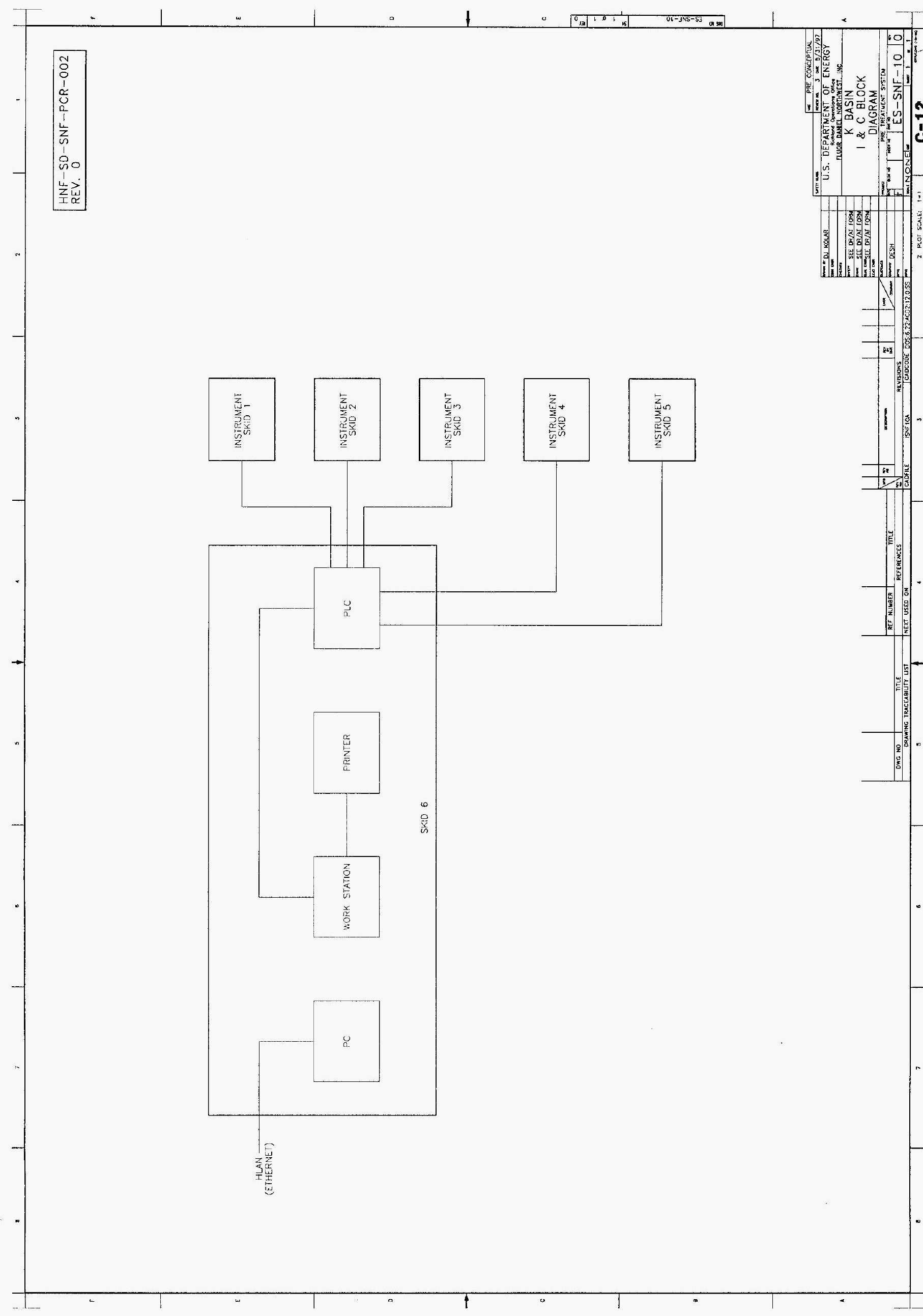

